\title{
A relook into the crustal architecture of Laxmi Ridge, northeastern Arabian Sea from geopotential data
}

\author{
Nisha NAiR ${ }^{1,3}$, S P AnAnd ${ }^{1}$, Mita Rajaram ${ }^{1, *}$ and P RAma RaO ${ }^{2}$ \\ ${ }^{1}$ Indian Institute of Geomagnetism, Navi Mumbai 410 210, India. \\ ${ }^{2}$ Andhra University, Vishakhapatnam 530 003, India. \\ ${ }^{3}$ Present Address: National Centre for Antarctic and Ocean Research, Goa 403 804, India. \\ ${ }^{*}$ Corresponding author. e-mail: mita@iigs.iigm.res.in
}

In this study, we undertake analysis of ship-borne gravity-magnetic and satellite-derived free-air gravity (FAG) data to derive the crustal structure of Laxmi Ridge and adjacent areas. 2D and 3D crustal modelling suggests that the high resolution FAG low associated with the ridge is due to underplating and that it is of continental nature. From Energy Spectral Analysis, five-depth horizons representing interface between different layers are demarcated that match those derived from 2D models. Magnetic sources from EMAG2 data, various filtered maps and absence of underplating in the EW section suggest that the EW and NW-SE segment of the Laxmi Ridge is divided by the Girnar fracture zone and probably associated with different stages of evolution. From the derived inclination parameters, we infer that the region to the north of Laxmi Ridge, between Laxmi and Gop Basins, is composed of volcanic/basaltic flows having Deccan affinity, which might have been emplaced in an already existing crust. The calculated inclination parameters derived from the best fit 2D model suggests that the rifting in the Gop Basin preceded the emplacement of the volcanics in the region between Laxmi and Gop Basins. The emplacement of volcanic/basaltic flows may be associated with the passage of India over the Reunion hotspot.

\section{Introduction}

Western continental margin of India (WCMI) is a typical volcanic passive margin evolved as the result of Mesozoic rifting of India from its counterparts and later passage of the Indian plate over the Reunion hotspot. WCMI and the adjoining landmass of Indian subcontinent witnessed large-scale magmatic activity related to the Reunion hotspot. WCMI comprises of several surface/subsurface structural features that include the Shelf Margin Basin, Chagos-Laccadive Ridge, Laccadive Basin, Laxmi Ridge (LR), Laxmi Basin (LB), Gop Rift Basin, etc., and a belt of numerous horst graben structures in the sediment filled basins bordering the west coast of India. The bathymetry of the WCMI including the study area is shown in figure 1. Superposed are the tectonic elements, magnetic lineations mapped from Bhattacharya and Chaubey (2001) and locations of the profiles selected for $2 \mathrm{D}$ crustal modelling. Several debates exist on the nature and evolution of these elements especially Laxmi Basin (Bhattacharya et al. 1994; Krishna et al. 2006), Chagos-Laccadive Ridge, etc. To have a better understanding of the evolution of the WCMI and the associated ocean floors, it is crucial to understand the structure, tectonics, evolution, and role of each of these tectonic elements in detail integrating all available information. With new datasets and applying new techniques to the existing datasets, one can extract more information. In keeping with this view, Nair et al. (2013)

Keywords. Laxmi Ridge; gravity; magnetic; rifting; tectonics. 


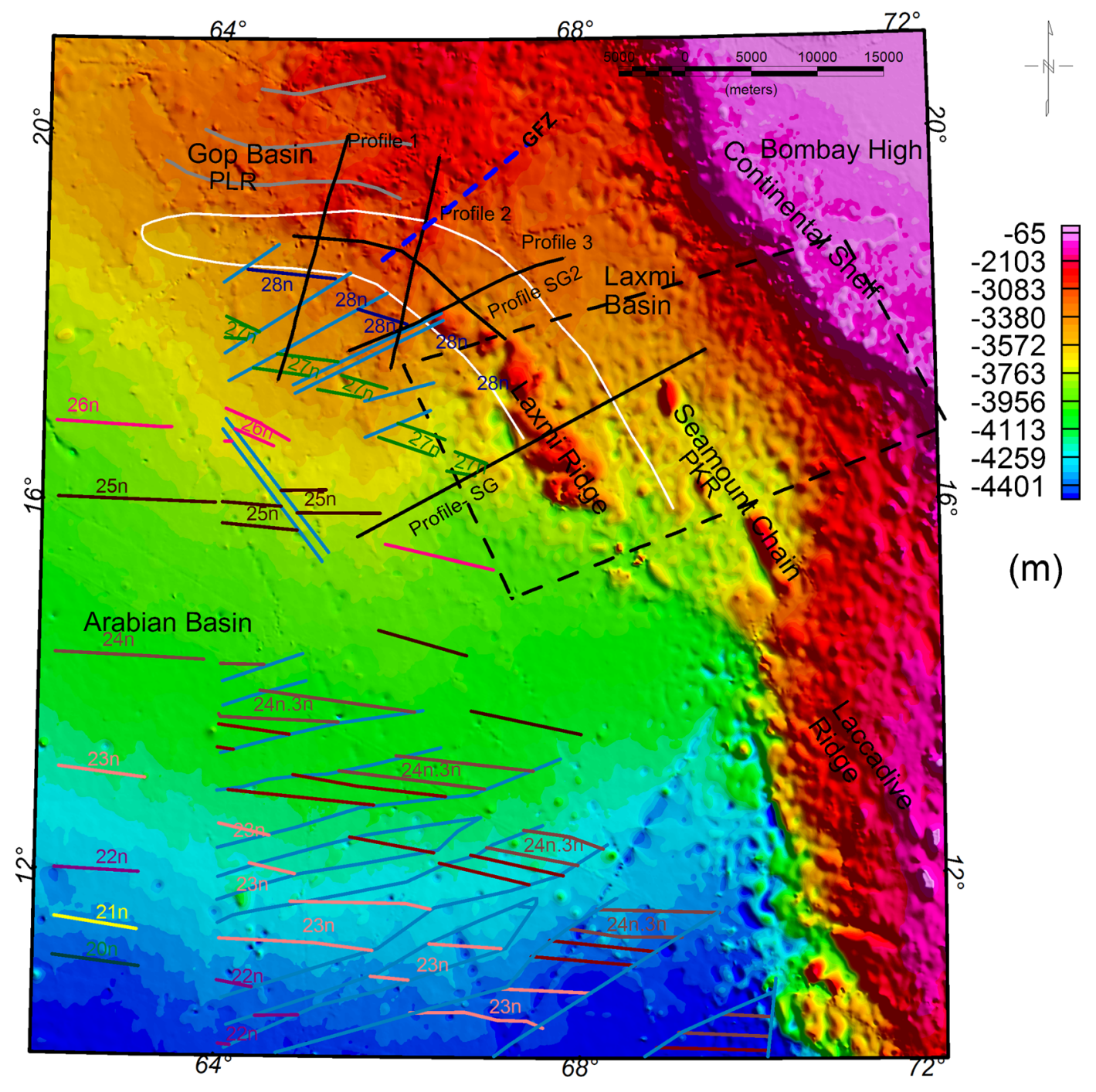

Figure 1. Bathymetry map of the western Indian Ocean. Outlined in white is the demarcation of Laxmi Ridge from Minshull et al. (2008). Superposed are the locations of three ship-borne gravity-magnetic profiles (1, 2 and 3) and SG1 and SG2 are the two profiles selected from satellite-derived gravity data (in black) used for 2D modelling. Demarcated in black dashed line is the area of study by Bhattacharya et al. (1994). The magnetic lineations and faults mapped by Bhattacharya and Chaubey (2001) and Yatheesh et al. (2009) are mapped. PKR and PLR represent the Panikkar and Palitana Ridges, respectively.

analyzed the free-air gravity (FAG) anomalies over the Laccadive Ridge and suggested an alternate model for the nature and evolution of the Laccadive Ridge. In the present paper, we analyze the high resolution satellite-derived new gravity data (Sandwell and Smith 2009) and ship-borne gravity and magnetic data to develop 2D crustal model of the Laxmi Ridge and adjoining areas. Further, we use the Multi Window Technique (Markham et al. 2008) to generate a 3D crustal model of the Laxmi Ridge. Utilizing these techniques, an attempt is made to improve our understanding of the crustal architecture and evolution of the Laxmi Ridge.

The Laxmi Ridge (LR), one of the most enigmatic features in the north-eastern Arabian Sea, named by Naini and Talwani (1977), has been investigated by various geophysical studies. The LR is about $100 \mathrm{~km}$ in width and runs over a length of approximately $700 \mathrm{~km}$ consisting of isolated submarine structural highs extending NWSE between latitudes $14^{\circ}-19^{\circ} \mathrm{N}$ and longitudes $64^{\circ}-69^{\circ} \mathrm{E}$. It has a rugged topography buried under $0.5-\mathrm{km}$ thick sediments and an average water depth of about $2.8 \mathrm{~km}$ (Naini 1980; Naini and Talwani 1982). In spite of having a prominent bathymetric high, Laxmi Ridge depicts a negative FAG anomaly. Based on associated characteristic gravity low and magnetic anomaly trends, it was deduced that around $65^{\circ} 30^{\prime} \mathrm{E}$ this ridge turns WNW-ESE and extends westwards at least up to $63^{\circ} 40^{\prime} \mathrm{E}$ (Miles and Roest 1993; Malod et al. 1997). Controversies exist regarding the nature of the Laxmi Ridge whether it is Continental (Naini and Talwani 1982; Kolla and Coumes 1990; Miles and Roest 1993; Miles et al. 1998; Krishna et al. 2006; Arora et al. 2012) or Oceanic (Pandey et al. 1995; 
Singh 1999; Rajaram et al. 2011). Chatterjee et al. (2013) discuss India's long voyage from Gondwana to Asia and document the complex nature of breakup of Seychelles and Laxmi Ridge. The controversies in delineating the crustal structure below the Laxmi Ridge led to diverse conclusions like the ridge acts as a transitional boundary between rifted transitional type of crust lying landward and an oceanic crust on the other side (Naini and Talwani 1982; Kolla and Coumes 1990; Miles and Roest 1993) or LR is flanked on both sides by crusts that are oceanic in nature (Bhattacharya et al. 1994; Malod et al. 1997; Chaubey et al. 1998). Earlier studies (Naini and Talwani 1982; Kolla and Coumes 1990; Miles and Roest 1993) considered the Laxmi Ridge to be a continental sliver with deep faulted basement. Based on the available ship-borne gravity, magnetic data, and seismic velocities, some researchers considered it to be an underplated normal oceanic crust buckled under a horizontal compressive regime (Pandey et al. 1995; Singh 1999; Todal and Edholm 1998) while others consider it to be a stretched continental crust developed under extension and rift related regimes (Bansal et al. 2005; Krishna et al. 2006). The presence of an anomalous $7.2 \mathrm{~km} / \mathrm{sec}$ lower crustal velocity layer below the ridge was interpreted as underplated material and that the LR is associated with thinned continental crust (Miles et al. 1998). Collier et al. (2008) from a forward model of the magnetic data, studied the rifting between the Seychelles and Laxmi Ridge by constraining the basement structure from wide angle seismic refraction and reflection data of Minshull et al. (2008) and interpreted the Laxmi Ridge to consist of transitional/intermediate crust. During the period 89 and $85 \mathrm{Ma}$, as Indian plate passed over the Marion plume, Madagascar separated from India (Agarwal et al. 1992; Storey et al. 1995) leading to conjugate spreading along the Mascarene and Palitana Ridges. By integrating seismic refraction and reflection, free-air gravity, magnetic anomaly data, and Ar dating of rocks, Mukhopadhyay et al. (2012) opined that spreading along the Palitana Ridge split the Laxmi Ridge and Seychelles from India (between 79 and $66 \mathrm{Ma}$ ). Further, Samal et al. (2012) from studies of high resolution seismic, free-air gravity and well data in the west coast of India suggested that the gravity low along the Laxmi Ridge is due to the down-warping at the lower crust as a result of excessive magmatic material below the ridge. From the foregoing we see that several, often conflicting, theories and hypothesis have been postulated for the structure and evolution of the Laxmi Ridge. In this paper, we undertake combined analysis of ship-borne gravity and magnetic data constrained by available refraction data along selected profiles to decipher the $2 \mathrm{D}$ crustal structure of the Laxmi Ridge and its surrounding region. Also, we utilize a multi-window power spectral method on the high resolution satellite-derived FAG anomaly data to derive 3D crustal structure of the Laxmi Ridge for understanding the evolution of this ridge.

\section{Methodology and interpretation}

To have an understanding of the crustal structure of the Laxmi Ridge and its surrounding region, a FAG anomaly map (figure 2) was generated using the satellite-derived (Sandwell et al. 2013) FAG data (v21.1). The FAG dataset used for the present study is obtained from a $1^{\prime} \times 1^{\prime}$ grid having an improved spatial resolution compared to the initial version (Sandwell and Smith 1997 used in Rajaram et al. 2011). Seafloor topography (version 15.1) derived from satellite altimetry with resolution of $1^{\prime}$ grid was used as bathymetric data for the present study. The FAG anomaly map generated using the above-discussed dataset is represented as a histogram equalized colour shaded image in which the warm and cool colours represent highs and lows, respectively (figure 2).

The rugged topography along the Laxmi Ridge is associated with a negative FAG anomaly of 10-50 mgal. They appear as individual highs along the ridge. Its north-westward extension remains almost flat without much topographical expression (Naini and Talwani 1982). In the north, the anomalously high Gop Rift Basin bears a negative gravity anomaly along its centre which coincides with the Palitana Ridge (Yatheesh et al. 2009). To the west, the negative anomalies in the Arabian Basin are subdued ranging from 10 to 15 mgal. The presence of seamount chains, to the east of the Laxmi Ridge, within the Laxmi Basin, appear as isolated circular/elliptical gravity highs within a gravity low extending NW-SE, known as Panikkar Ridge (Gopala Rao et al. 1992). Continental shelf bordering the west coast of India appears anomalously high followed by a gravity low in the shelf margin basin (to the west of shelf). Within the continental shelf lies the low gravity, Bombay High sedimentary basin.

EMAG2 (Earth Magnetic Anomaly Grid) data compiled from satellite, ship and airborne magnetic measurements (Maus et al. 2009) were utilized to generate the magnetic anomaly map shown in figure 3. It has a resolution of 2 arc min grid with an altitude of $4 \mathrm{~km}$ above the geoid. The magnetic anomalies trending parallel to the isochrones (lines of equal age) in the oceans reveal the temporal evolution of oceanic crust (Müller et al. 2008). The magnetic anomaly map from EMAG2 data shows several interesting features along the Laxmi 


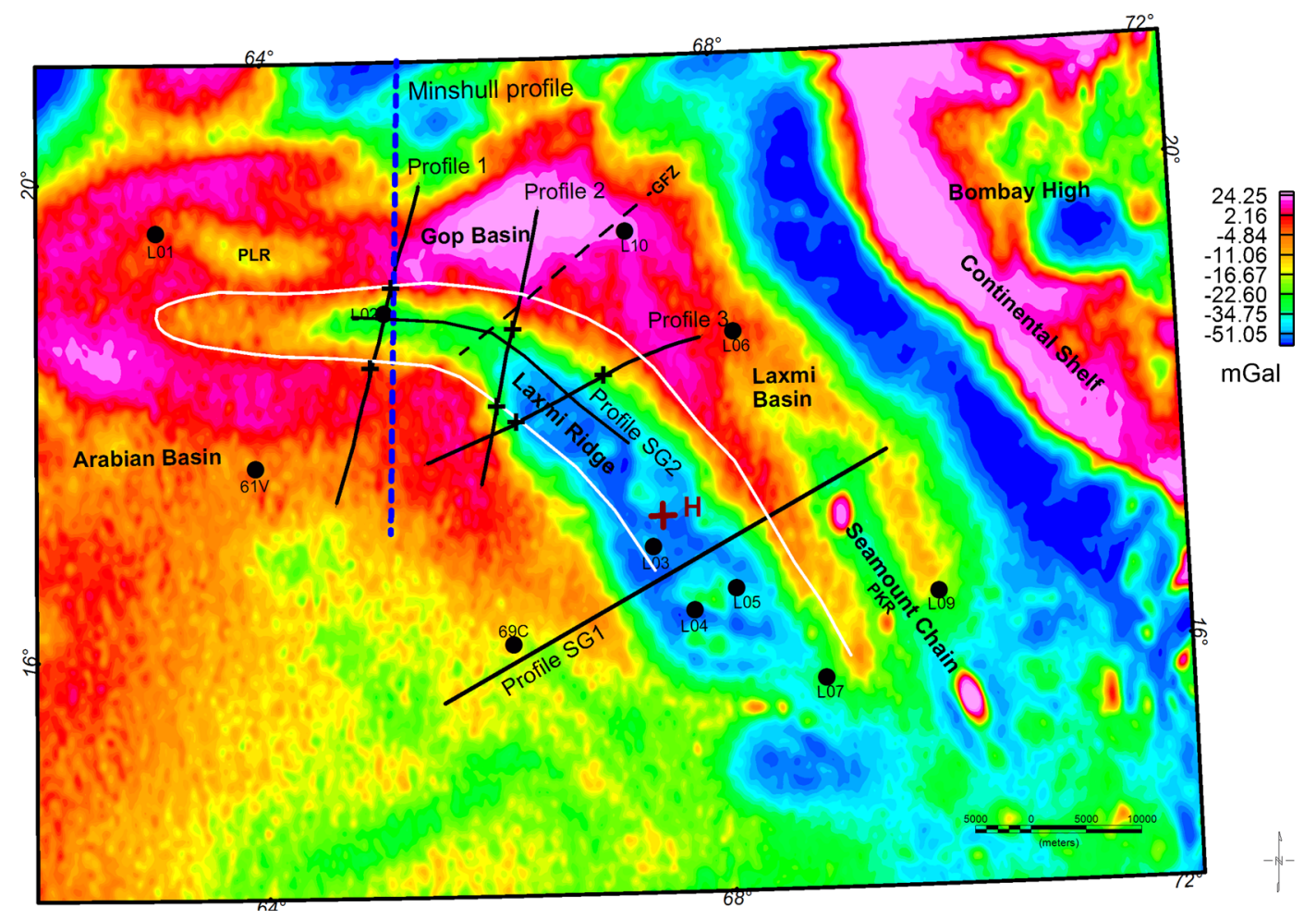

Figure 2. FAG anomaly map of the study region. Outlined in white is the demarcation of Laxmi Ridge from Minshull et al. (2008). Blue dashed line represents Minshull's (2008) OBS profile location. Superposed are the sonobuoy refraction station locations (Naini and Talwani 1982) in black dots. Superposed are the locations of three ship-borne gravity-magnetic profiles (1, 2 and 3) and SG1 and SG2 are the two profiles selected from satellite-derived gravity data (in black) used for 2D modelling. Also superposed in black cross are the width of the Laxmi Ridge as calculated from the analytic signal of the profiles; $\mathrm{H}$ (in maroon cross) denotes the location of horizons mapped from MWT analysis (shown in figure 5a). GFZ, PKR and PLR represents the Girnar fracture zone, Panikkar and Palitana Ridges, respectively.

Ridge and adjacent regions. The identified seafloor spreading magnetic lineations (after Chaubey et al. 2002; Yatheesh et al. 2009 and references therein) within the study area are superposed on this map (figure 3). The magnetic anomalies within the Arabian and Gop Rift Basins trend in EW to ENE-WSW while in the Laxmi Basin, they appear NW-SE in general. The Laxmi Ridge mainly depicts subdued magnetic anomalies except for a linear positive magnetic anomaly marked as L1 (figure 3) which appears to divide Laxmi Ridge into a NW-SE segment and EW segment. It can be seen that to the southeast of L1 within the Laxmi Ridge, the magnetic anomalies trend NWSE. It is exactly at the location of L1 the gravity anomaly also changes its characteristic, i.e., a relative high on the EW part and a low in the NWSE segment. Magnetic signatures and their distinct patterns illustrate various aspects of Earth evolution such as sea-floor spreading and subduction of oceans, formation of continental crust by accretion, large scale volcanism, etc.

To delineate the crustal structure, a 2D crustal model of the Laxmi Ridge was developed along selected profiles of ship-borne gravity, magnetic and bathymetry data (NGDC, Marine Trackline
Geophysics dataset, version 5.0.11), in section 2.1. An attempt was made in section 2.2, to generate a 3D crustal model of the Laxmi Ridge using MultiWindow Technique (MWT) which helps to map the geological horizons or trends from the satellitederived FAG data. Further, to isolate the shallow and deeper features, in section 2.3, the FAG data was subjected to wavelength filtering for different cut-off wavelengths. To understand the distribution of the sources, analytic signal of FAG and EMAG2 was generated in section 2.4.

\section{$2.12 D$ crustal modelling}

To delineate the nature and configuration of the Laxmi Ridge ship-borne magnetic and gravity data (National Geophysical Data Centre - NGDC 2003) along three profiles (location shown in figure 1), cutting across the ridge have been modelled. The computational method used for the forward crustal modelling using the GM-SYS software is based on the methods of Talwani et al. (1959) and Talwani and Heirtzler (1964) using the algorithms described in Won and Bevis (1987). Forward modelling involves creating a hypothetical geologic model and calculating the geophysical response to that earth model. 


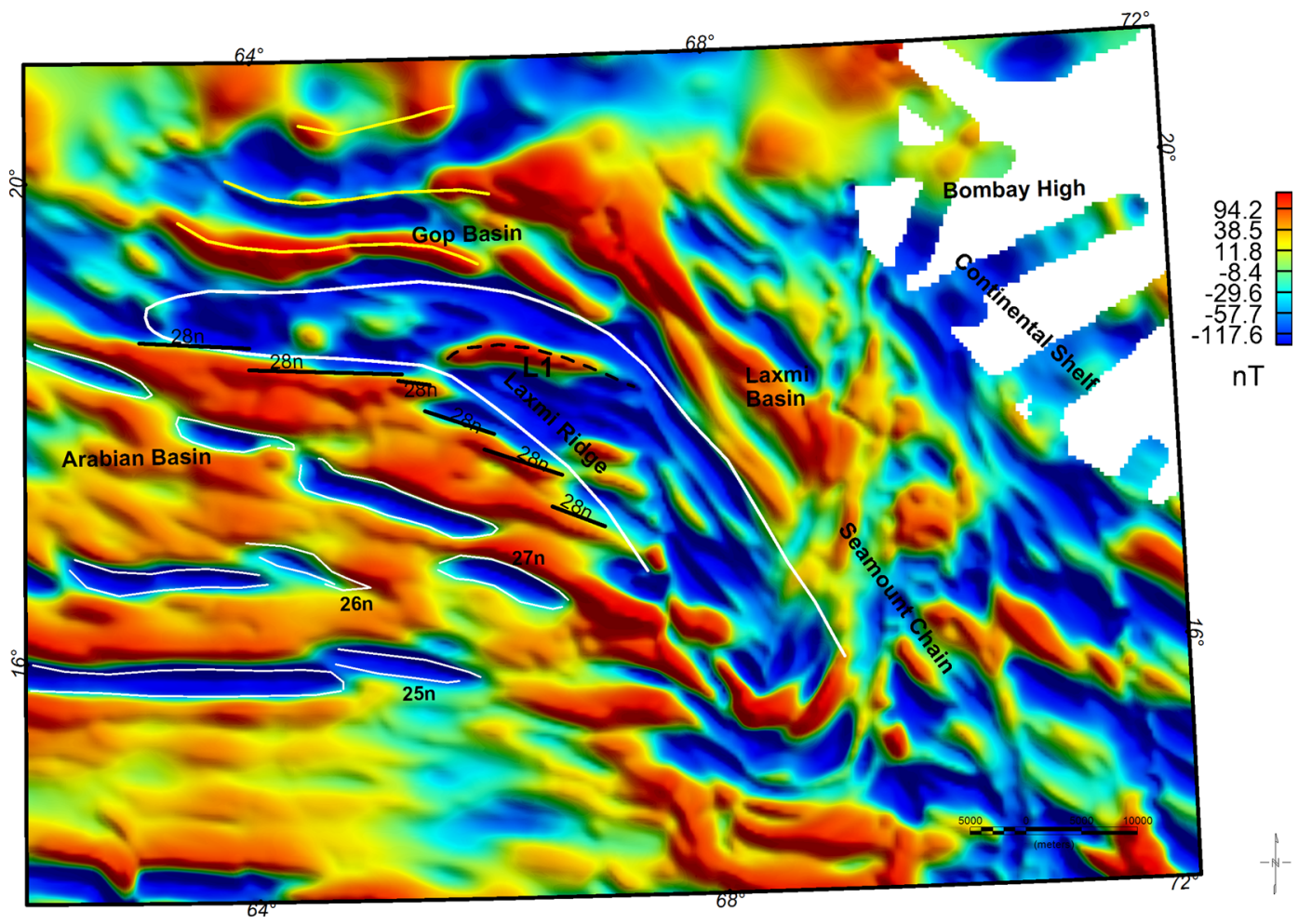

Figure 3. Map of EMAG2-Earth magnetic anomaly grid of the study area (Maus et al. 2009 at an altitude of $4 \mathrm{~km}$ ). Magnetic lineations mapped from Chaubey et al. (2002) are superposed in white (25n, 26n, 27n) and black lines (28n). Marked in yellow are the magnetic lineations identified in the Gop Basin (Yatheesh et al. 2009). Mapped in thick white is the outline of the Laxmi Ridge demarcated from Minshull et al. (2008) and marked in yellow dashed line is L1 as discussed in the text.

Profile 1 runs almost NS, close to the ocean bottom seismic (OBS) profile of Minshull et al. (2008), cuts across a part of Gop Rift (to the north), EW part of Laxmi Ridge and Arabian Basin cutting A28N. The water depths and sediment thickness have been obtained from the bathymetry and isopach maps (Schreider et al. 2002). For the entire profile, the layer of water column was given a density of $1030 \mathrm{~kg} / \mathrm{m}^{3}$ followed by a sedimentary layer of $2200 \mathrm{~kg} / \mathrm{m}^{3}$ (figure 4 ). The densities for the crustal layers were derived from the sonobouy seismic refraction velocities (Naini and Talwani 1982) using Nafe and Drake (1963) curve; the initial thickness of the crustal layers are also taken from Naini and Talwani (1982). Even though there are limitations in correlating highly reflective seismic layers as density layer boundaries, as shown by previous studies (Long 2010; Radha Krishna et al. 2002), the inferred densities would still be useful to derive broad crustal density configuration. The location of the seismic refraction stations are superposed on figure 1. In all the modelled profiles shown in figure 4, the seismic velocity and derived density are superposed on the crustal structure. For the central part of profiles 2 and 3, across the Laxmi Ridge, a three-layer crust with a high density layer just above the mantle was assumed with the thickness and velocities calculated from seismic refraction stations L03, L04, L05, and L07. The layer of high density found along refraction stations discussed above was absent in refraction station L02, which was used for modelling profile 1. From the seismic velocity structure, the Laxmi Basin also depicts three layers above the Mantle albeit with densities slightly different from the Laxmi Ridge. The thicknesses of the crustal layers and Moho were iteratively varied to minimise the RMS error between the observation and model response. We would like to point out that the profile 1 is close to Minshull et al. (2008) OBS profile. An attempt was made to generate a gravity model for profile 1 , using densities derived from the velocity structure (utilizing Nafe-Drake curve for conversion) and crustal depths as obtained by the Minshull et al. (2008). It was noticed that the introduction of a lower velocity layer (underplating) below the Laxmi Ridge did not produce a good fit between the observed and calculated anomaly. Therefore a $2 \mathrm{D}$ crustal model was generated without any prior assumptions whether underplating is present or not.

The 2D models presented in this paper are combined modelling of gravity-magnetic data. The crustal model generated using the gravity data, is used as the basic crustal structure for modelling the magnetic data. In addition, for modelling of the shipborne magnetic data we follow the methodology 

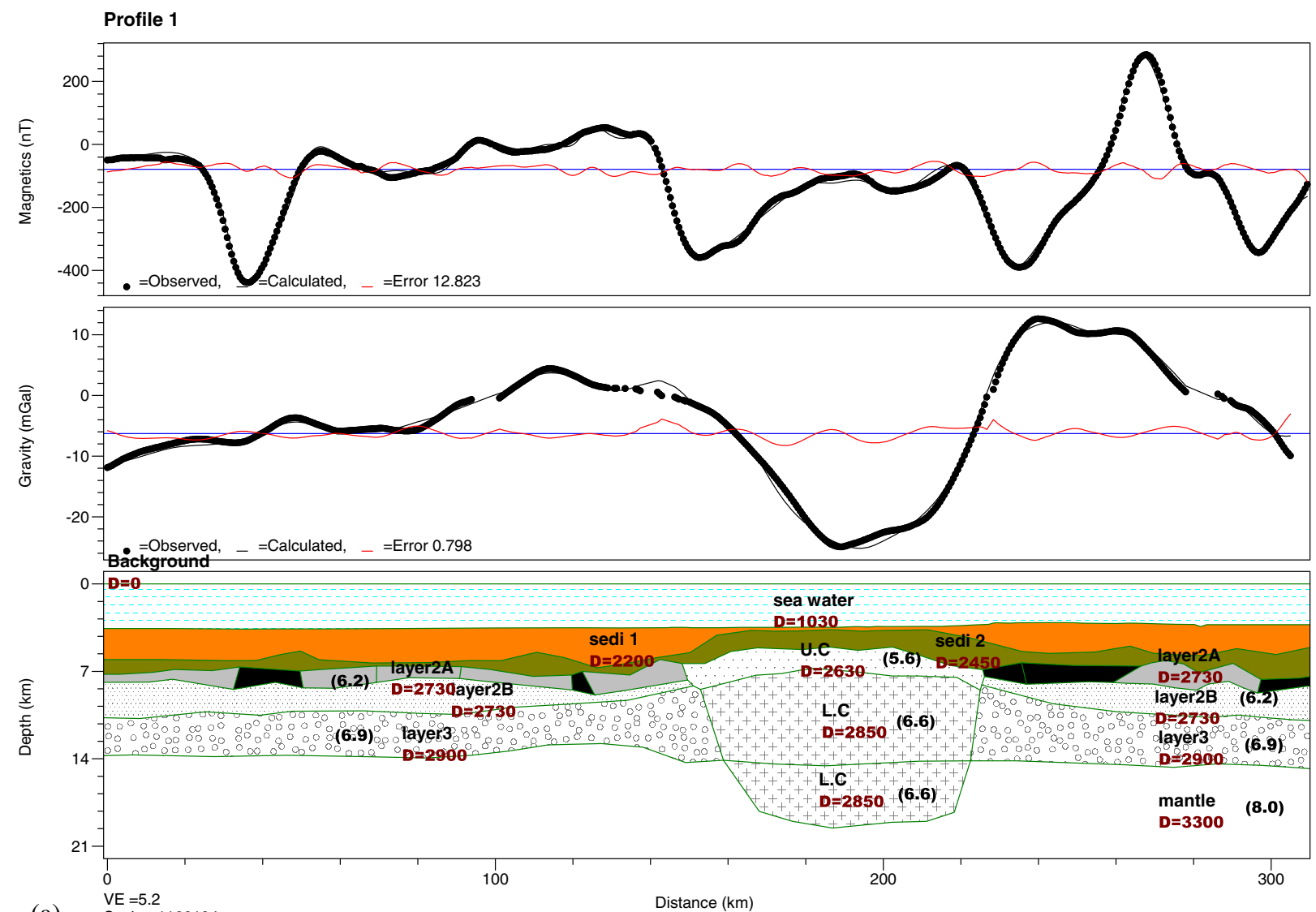

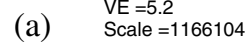
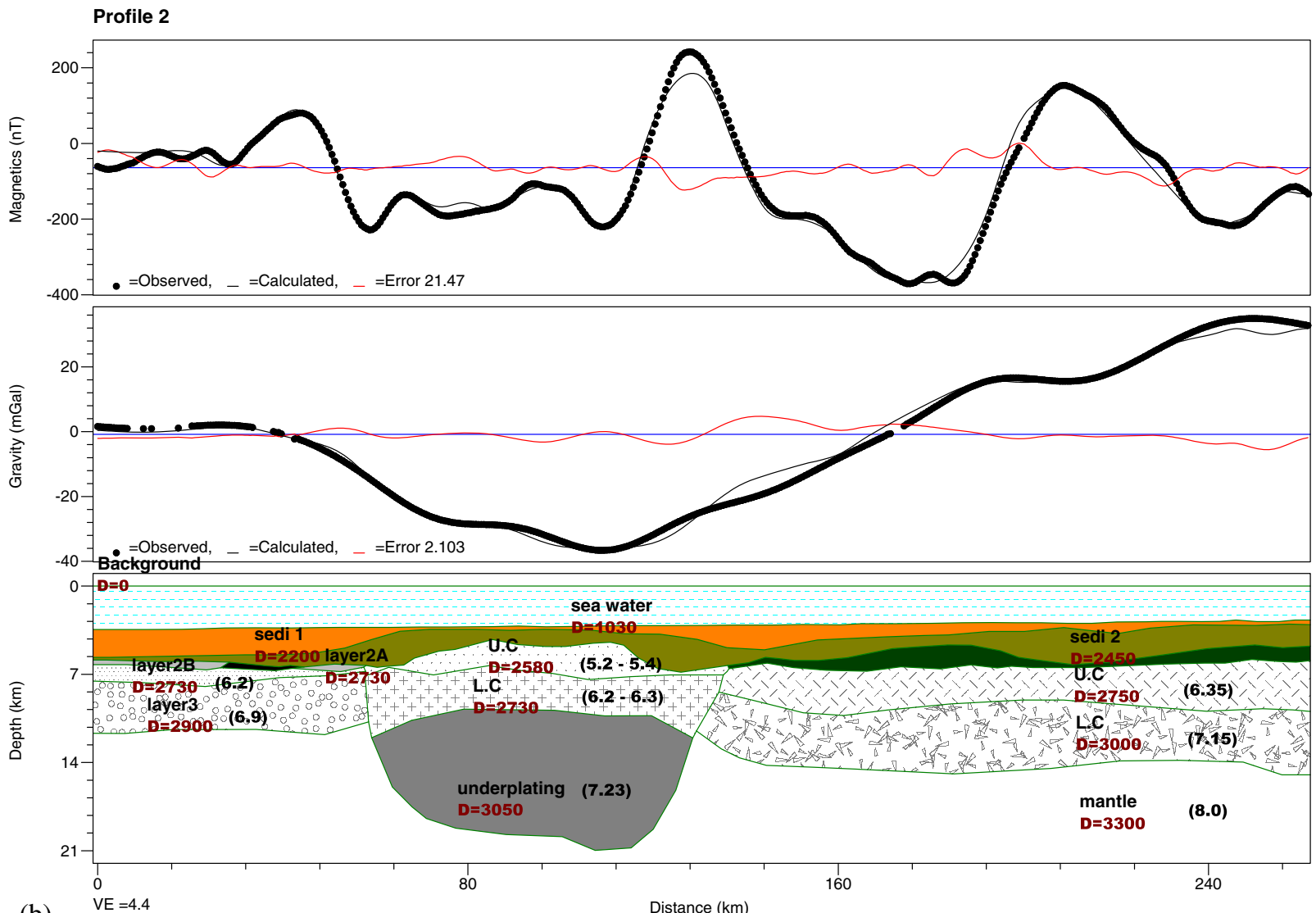

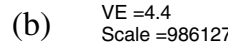

Distance (km) 


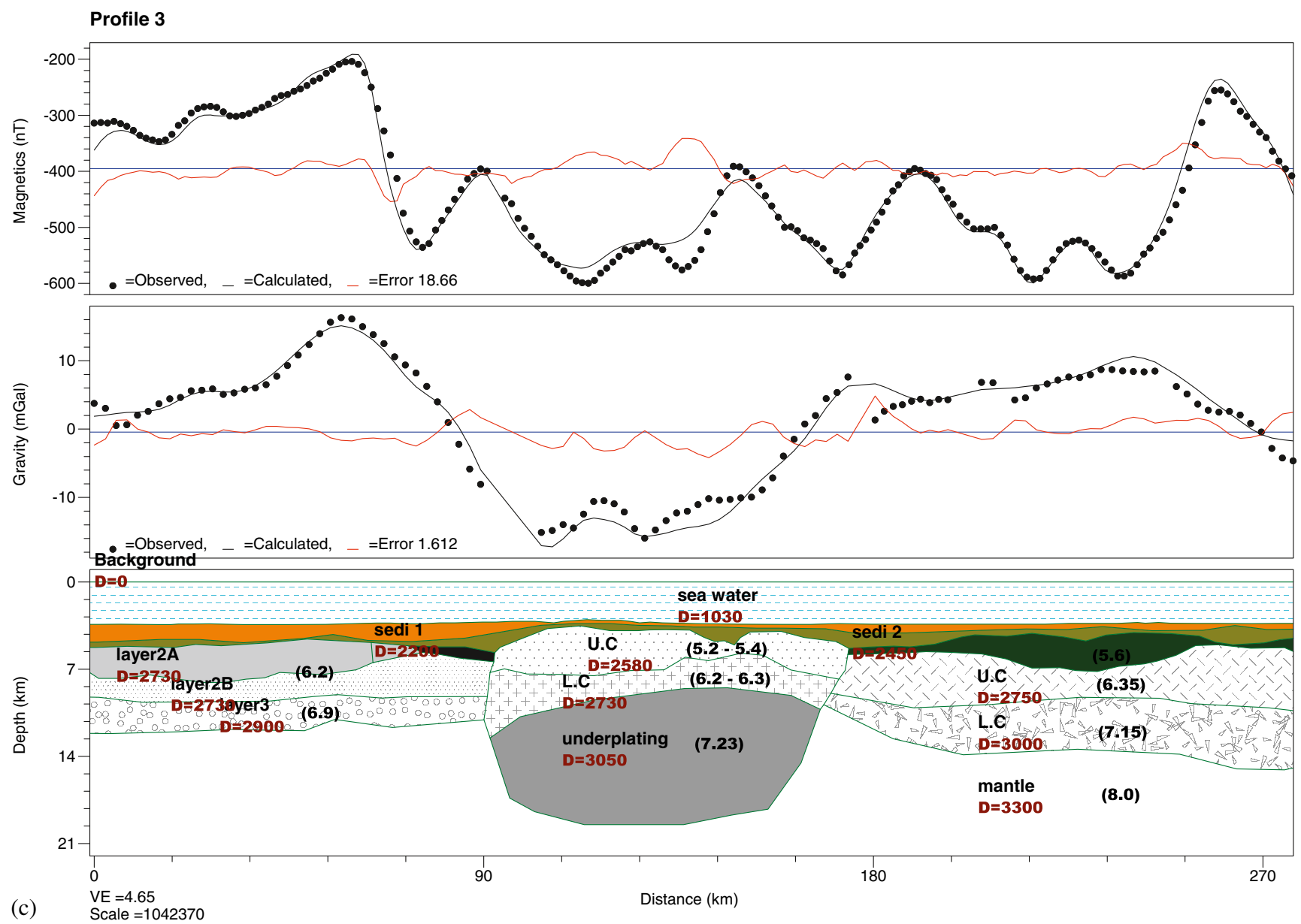

Profile SG1

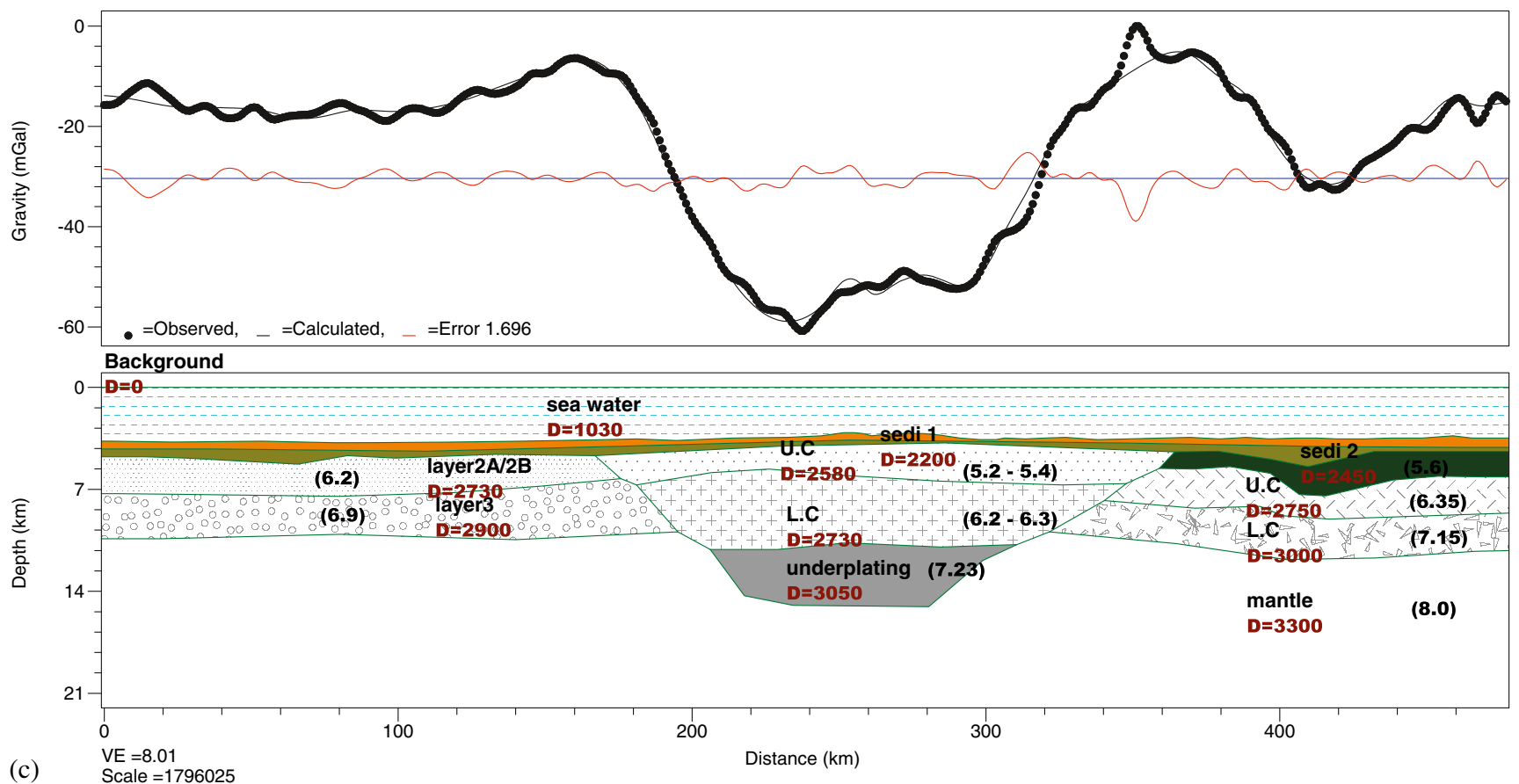


Profile SG2

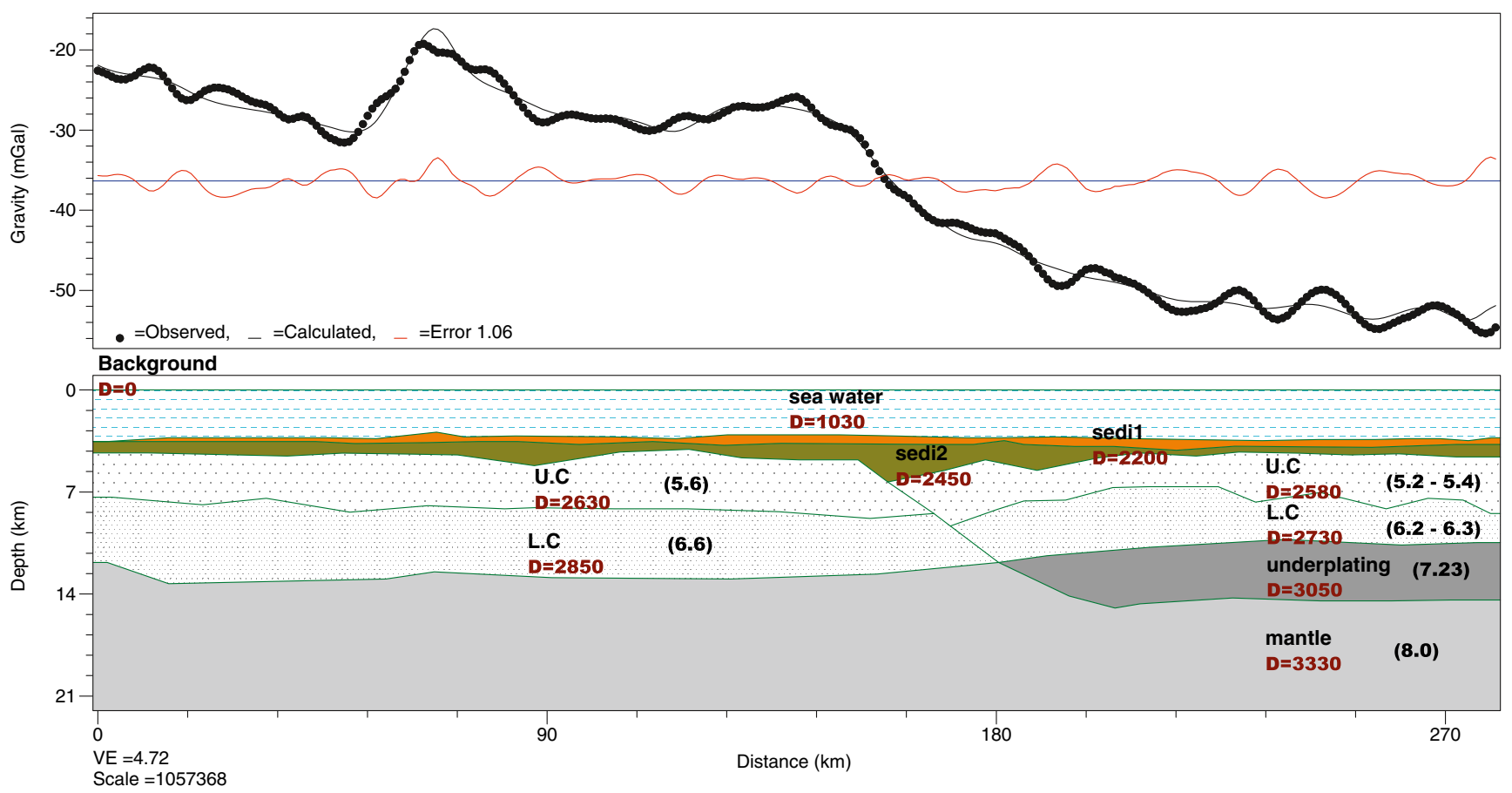

Figure 4. Crustal model derived from the ship-borne gravity and magnetic data analysis along profiles across the Laxmi Ridge: (a) profile 1, (b) profile 2, (c) profile 3; (d) crustal model derived from satellite-derived FAG data over profile SG1, and (e) SG2. The water depths and sediment thickness (orange coloured) have been obtained from the bathymetry and isopach maps. Dotted lines in black represent the observed gravity and magnetic data while the full lines depict the calculated values and the thin red lines depict the errors. The magnetic polarity in layer $2 \mathrm{~A}$ are represented by black for normal and grey for reverse polarity. Green colour denotes the volcanics. The seismic velocity and derived density are superposed on the crustal structure.

used by Anand et al. (2009). To start with, magnetic susceptibilities for the Laxmi Ridge and oceanic region were taken as 0.035 SI and 0.04 SI, respectively (Rajaram et al. 2009) for the upper crust. A three-layer crustal model (Kent et al. 1993) was adopted for the oceanic crust (Arabian Basin and Gop Rift) and below the Laxmi Ridge a twolayer - upper and lower crustal layers was adopted. According to Kent's model, the upper crust in the oceanic region is divided into layer 1 - the sedimentary layer, layer 2 - the upper oceanic crust, consisting of $2 \mathrm{~A}$ (pillow basalts) and $2 \mathrm{~B}$ (sheeted dykes) with high magnetization in layer $2 \mathrm{~A}$, and both the layers $2 \mathrm{~A} / 2 \mathrm{~B}$ depicting the same density, and a third layer 3 (gabbros with less magnetization compared to the upper layers) considered as the lower oceanic crust, lies below the extrusive layer $2 \mathrm{~B}$. To start with, for the oceanic region we introduced a higher magnetization $(\sim 6$ to $8 \mathrm{~A} / \mathrm{m})$ in the extrusive upper layer $(2 \mathrm{~A})$ with positive and negative inclination parameters for the reverse and normal polarities respectively and magnetization of $\sim 1.1 \mathrm{~A} / \mathrm{m}$ in the layers $2 \mathrm{~A}, 2 \mathrm{~B}$, and 3 . The presence of magnetic lineations were incorporated from the EMAG2 (Maus et al. 2009) data (figure 3). The inclination (Dyment et al. 1994) of the well-established magnetic lineations 27n and 28n in the Arabian Basin were introduced as a starting point for the magnetic model along profile 1 (figure $4 \mathrm{a}$ ). The location of the $27 \mathrm{n}$ and $28 \mathrm{n}$ anomaly was picked from the welldefined peaks obtained from the analytic signal of the NGDC magnetic profile data. Similarly towards the north of the Laxmi Ridge, in the Gop Rift Basin, a positive linear magnetic anomaly from the EMAG2 (profile 1, figure 3) data was picked up (the known Palitana Ridge) and the magnetizations were given considering it to be oceanic (Yatheesh et al. 2009). For the Laxmi Ridge (continental), while the upper crust was given a magnetization of about $\sim 2.95(\mathrm{~A} / \mathrm{m})$, the lower crust was assigned a susceptibility of 0.005 SI and assumed to be devoid of any remanence. The edges of the Laxmi Ridge were demarcated from the peaks obtained from analytic signal of the respective gravity profiles. The polarities of the $2 \mathrm{~A}$ layer of the profile in the Arabian and Gop Rift Basins are found iteratively through modelling. The magnetizations were iteratively adjusted to minimize the error difference between the observed and calculated magnetic anomalies. Another model assuming intrusives in the Gop Basin instead of sea-floor spreading anomalies was attempted and it was seen that the RMS misfit was beyond acceptable limit. Hence this model was not considered. It may be noted 
that the final crustal model is a best fit model to both the gravity and magnetic data and the calculated magnetic parameters are derived from this model fit of the entire profile and not just from individual anomaly. In the final model, the inclination for the sea floor spreading in the Gop Rift varies between $47^{\circ}$ and $49^{\circ}$ for the reverse $(+)$ and normal $(-)$ magnetisation (in the southern hemisphere).

Profiles 2 and 3 (figure $4 \mathrm{~b}$ and c) cut across the Laxmi Ridge in the centre and Arabian Basin to the southwest. In the northeast, it may be noted that these two profiles fall in the region (a) between the Gop and Laxmi Basins, to the southeast of where Chatterjee et al. (2013) reported the presence of Somnath volcanism, (b) northeast of Laxmi Basin where Bhattacharya et al. (1994) reported sea floor spreading anomalies, and (c) where Malod et al. (1997) assumed the spreading axis of the Gop Rift could be extrapolated to join with the spreading axis of the Laxmi Basin. For profiles 2 and 3, the location of anomaly $28 \mathrm{n}$ in the Arabian Basin was incorporated in both the profiles as the starting model. The black colour represents normal polarity in figure $4(\mathrm{a}-\mathrm{c})$, while the grey colour represents the reverse polarity. The crustal nature of Laxmi Basin is debated (Bhattacharya et al. 1994; Krishna et al. 2006); however, the region between the Laxmi and Gop Basins is less studied. For the forward modelling of profiles 2 and 3 within this region, we considered the band-pass filtered gravity data of profile 2 and 3 with cut-off wavelengths between 50 and 150 $\mathrm{km}$, so as to retain the signatures of the intermediate (crustal) levels only, i.e., avoiding the gravity signatures from water column, sediments, and Moho. We started initially by keeping the densities / magnetizations of the sedimentary and Moho layer as zero and tried out three possibilities; we first assumed the crust to be oceanic by incorporating spreading type anomalies to the upper layer as done for profile 1 . The response of the model thus generated was compared with the band-pass filtered gravity data of profile 2 and 3 . Second, we modelled assuming intrusives within the crust and again compared with the band-pass filtered data. In both the cases the match was not reasonable. Third, we introduced volcanic flows/basalts, calculated the model response and on comparison with the bandpass data, found that the fit was reasonably good. The top layer of the upper crust was found to have much higher magnetization $(\sim 7 \mathrm{~A} / \mathrm{m})$ for the best fit model. In our final $2 \mathrm{D}$ models, we were able to reproduce the magnetic anomalies over this region by the introduction of the volcanic flows/basalts (figure $4 \mathrm{~b}, \mathrm{c}$ ). The lower crust was devoid of magnetization. The figure reproduced here is the final crustal structure derived for the entire crust as described for profile 1. Further, it was heartening to see that at the intersection point of the profiles 2 and 3 (figure 1) in the Arabian Basin, the crustal structure matched very well bearing a positive magnetic anomaly. From the generated 2D models, we obtained inclinations of $-50^{\circ}$ for the basaltic/ volcanic flows in the region between Laxmi and Gop Basins for profiles 2 and 3.

$2 \mathrm{D}$ crustal structure was also generated along a fourth profile SG1 (towards southern part of the ridge) - using satellite FAG data (location given in figure 1) as ship-borne gravity and magnetic data were not available in this region. The $2 \mathrm{D}$ crustal structure was developed following the procedure similar to that done for the ship-borne gravity data (figure 4d). A higher density layer below the crust of the Laxmi Ridge was found in this profile as well. The presence of underplated layer in profiles 2, 3 and SG1 along the ridge axis in figure $4(\mathrm{~b}-\mathrm{d})$ lends credence to the model derived from both the ship-borne and satellite data. A gravity profile running along the $\mathrm{E}-\mathrm{W}$ and $\mathrm{NW}-\mathrm{SE}$ axis of the Laxmi Ridge (SG2 in figure 1) was also modelled to check the nature of the crust along the ridge (figure 4e). A clear change in the gravity anomaly value was visible between the $\mathrm{E}-\mathrm{W}$ and NW-SE axis of the ridge with free air anomaly values changing from -22 to -54 mGals suggesting a change in the crustal structure. The derived crustal model also showed the presence of high density material below the crust of Laxmi Ridge in NW-SE axis whereas it was absent below the EW part. This derived crustal model along the Laxmi Ridge represented by profile SG2 reconfirms the absence of underplated material in the E-W axis of the Laxmi Ridge.

From the comparison of the generated 2D models, it was observed that the presence of underplating was confined only to the NW-SE (figure 4b-e) segment of the ridge. This suggests, that the nature of the ridge on the $\mathrm{E}-\mathrm{W}$ and NW-SE axis is different. Also the region between Laxmi and Gop Basins is associated with volcanic/basaltic flows rather than sea-floor spreading anomalies or intrusives.

\section{$2.23 D$ crustal structure energy spectral analysis $(E S A) /(M W T)$}

To generate a 3D crustal model of the Laxmi Ridge, we applied Multi-Window Technique (Markham et al. 2008), a modified form of Energy Spectral Analysis (ESA) (Markham et al. 2008) to the satellite-derived FAG anomaly data over the ridge. In MWT, energy decay spectra are calculated over a series of increasingly larger windows centered over point of interest. Depth-plateaus indicating nearly constant depth values for a range of window size corresponding to the approximate depth to the causative magnetic/gravity interface are thus determined. Multiple linear segments (slopes) on the spectrum correspond to separate depth 
ensembles, implying multiple inhomogeneities. The 1st slope, the steepest one corresponds to deeper interfaces dominating the low frequency zone while the 2nd slope indicates the average depth to the shallower sources and so on. The depth estimates heavily depend on the slope of the power spectrum; a change in the slope can vary the depth to the top of the interface. In the present paper, the slopes are fitted to the curve using the linear approximation. The fit with minimum standard deviation was used to calculate the depths.

We have taken around 60 locations (point of interest) along the Laxmi Ridge and window length ranging from 20 to $200 \mathrm{~km}$ with window expansion increment of $10 \mathrm{~km}$. Figure 5(a) represents the different depth horizons mapped using MWT technique for location $\mathrm{H}$ shown in figure 2. The marked plateaus represent the different horizons where the depth is not changing suggesting it to be a major density interface. This location being at the edge has only three horizons compared with the other regions well within the Laxmi Ridge. Five different depth-horizons were present for the locations of the Laxmi Ridge trending in NW-SE direction while in the EW part, only four horizons were present, the two deepest horizons are shown in figure $5(\mathrm{a}$ and $\mathrm{b})$. Comparison with the $2 \mathrm{D}$ models and seismic refraction data (Naini and Talwani 1982) suggests that Horizon 1 matched with the depth to the top of the sedimentary layer, Horizon 2 represents interface between sediments and depth to the top of the crust, Horizon 3 matched with the interface between upper and lower crust and Horizon 4 , depicted the depth to the interface between the lower crust and underplating. Horizon 4, i.e., the interface between lower crust and underplating was absent below the EW part of the Laxmi Ridge. The fifth and deepest horizon (Horizon 5) at an average depth of $24 \mathrm{~km}$, is present throughout the axis of the ridge, suggesting the thickened nature of the Laxmi Ridge and matches well with the Moho depth estimated from the 2D models. This explains the presence of an underplated layer below the ridge along the profiles 2, 3, SG1 and part of SG2 (figure 4b-e). The horizon H5 can be clearly visualized all along the Laxmi Ridge but as we move towards Laxmi Basin there is a shallowing of the Moho. The underplating is not present along profile1. It was found that the depths to the lower crust from the 2D profile models (figure 4) as well as the Moho depth matched reasonably well with the horizon depths obtained from the MWT analysis (table 1).

\subsection{Filtered FAG maps}

The long wavelength features are generally associated with the deep/regional sources and short wavelength features depict shallow sources, therefore wavelength filtering analysis of the FAG data was undertaken to understand the nature of the shallow and deep sources. FAG anomaly was subjected to high pass filtering with cut-off wavelengths of $50,80,100$, and $150 \mathrm{~km}$. The patterns did not change very much for the different cut-off wavelengths and a representative map at $100 \mathrm{~km}$ cut-off wavelength is shown in figure 6(a); the highs appear to demarcate the edges of the LR. Also several circular highs, possibly representing intrusives, are seen along the NW-SE segment while they are absent in the EW part. In the Gop Rift Basin, the anomalies trend in an E-W direction and show some similarity to the magnetic anomalies (figure 6a). When subjected to low pass filtering with cut-off wavelengths of $200 \mathrm{~km}$ (figure 6b), the NW-SE segment of the Laxmi Ridge appears as a smooth gravity low (ranging $\sim 10$ to $12 \mathrm{mGal}$ ) devoid of any anomalous sources, which were present in the high pass filtered maps (figure 6a). To the north of Laxmi Ridge, at the intersection of Gop Rift and Laxmi Basin, high anomalous zone was observed in the long wavelength maps (ranging from $\sim 16$ to $20 \mathrm{mGal})$.

\subsection{Source distribution/analytic signal}

To have an understanding of the distribution of gravity and magnetic sources at relatively shallow levels, analytic signal maps were generated from the FAG data and EMAG2 data and are reproduced in figure $7(\mathrm{a}$ and $\mathrm{b})$, respectively. The analytic signal method (the total gradient method) is used for defining the edges (boundaries) of geologically anomalous density or magnetization distributions (Nabighian 1972, 1974) and is independent of the magnetization directions. Mapped maxima (ridges and peaks) in the calculated analytic signal of gravity/magnetic anomaly map locate the anomalous source body edges and corners (e.g., basement fault, block boundaries, basement lithology contacts, fault/shear zones, igneous and salt diapirs, etc.).

From the analytic signal of the FAG, we find that to the east, prominent sources are picked from the continental shelf edge, Bombay High, and the seamount chains south of the Laxmi Basin (figure 7a). Laxmi Ridge reflects high gradients compared to the Laxmi Basin (to the east) and Arabian Basin (to the west). Within the Laxmi Ridge, the anomalous sources are mainly concentrated to the NW-SE part of the Ridge constrained by L1. The western edge of the magnetic lineament L1 lies parallel to the Girnar fracture zone (figure 2) (Malod et al. 1997). 

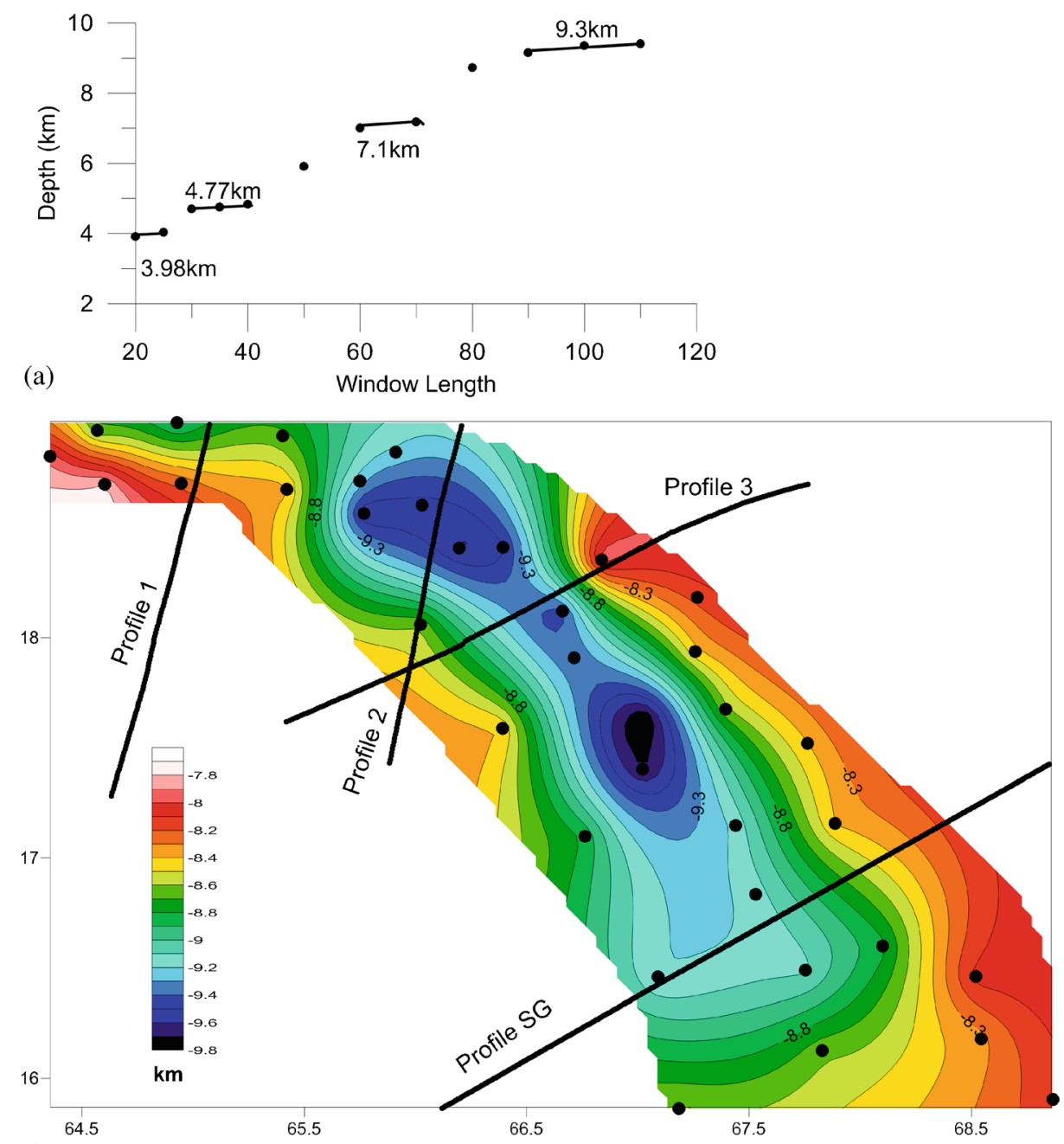

(b)

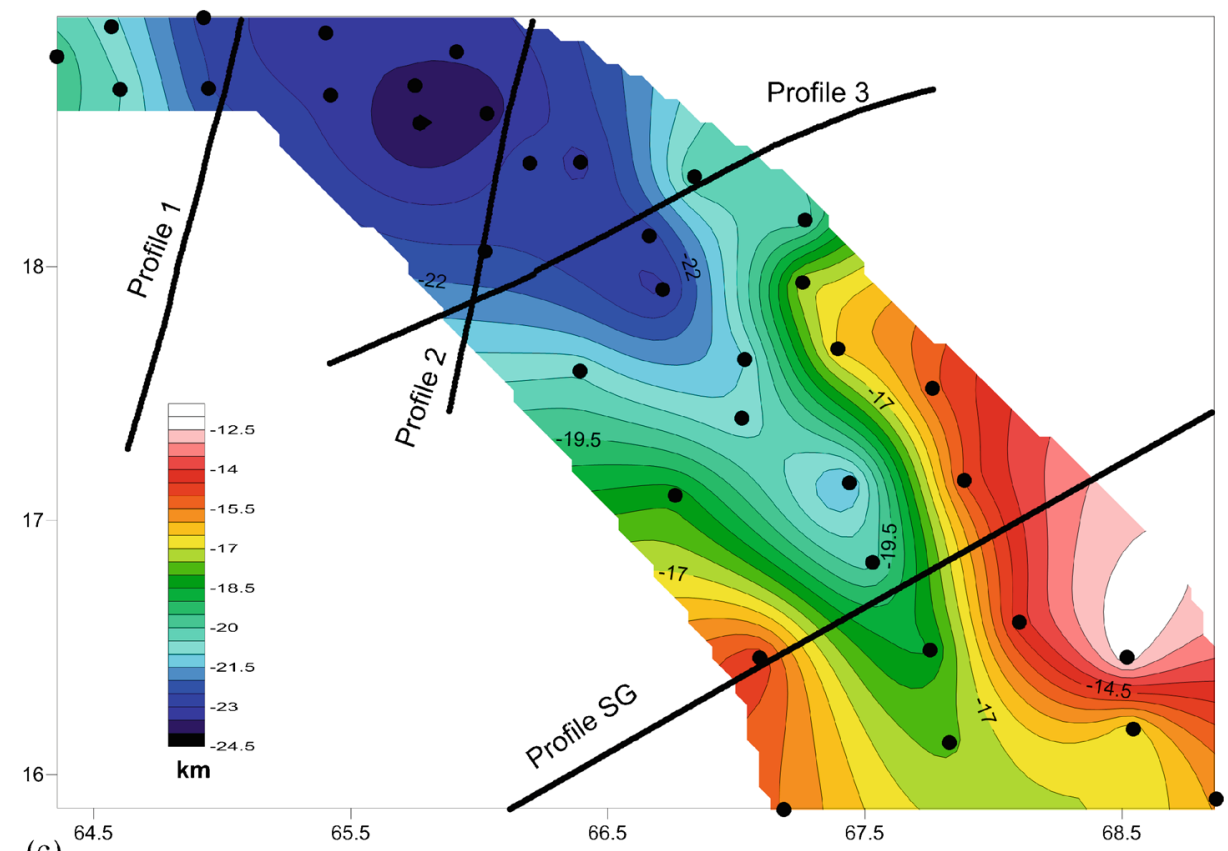

Figure 5. Horizon-depth map of Laxmi Ridge derived from MWT analysis of FAG data in 2D perspective. (a) Different depth horizons mapped using MWT technique for a selected location $(\mathrm{H})$ which is demarcated in figure 2; (b) representing the interface (H4) between lower crust and the underplating; and (c) showing the deepest horizon (H5) representing Moho depth. 
Table 1. Comparison of depths (average) obtained for horizons $H_{4}$ (interface between lower crust and underplating) and H5 (Moho) from the calculated MWT and $2 D$ models for the profiles 1, 2, 3 and SG1.

\begin{tabular}{lcc}
\hline & $\begin{array}{c}\text { MWT depths } \\
(\mathrm{km})\end{array}$ & $\begin{array}{c}\text { Depths from } \\
\text { 2D crustal } \\
\text { modeling }(\mathrm{km})\end{array}$ \\
\hline $\begin{array}{l}\text { Profile 1 } \\
\text { Crust-Mantle }\end{array}$ & $\sim 22.5-23$ & $\sim 18.35-19.67$ \\
Profile 2 & & \\
LC-UP & $\sim 8.4-9.5$ & $\sim 9.64-10.17$ \\
Crust-Mantle & $\sim 22-23$ & $\sim 20.01-20.97$ \\
Profile 3 & & $\sim 8.67-10.5$ \\
LC-UP & $\sim 8.1-9.3$ & $\sim 18.45-19.55$ \\
Crust-Mantle & $\sim 20.5-22.5$ & \\
Profile SG1 & & $\sim 10.63-11.11$ \\
LC-UP & $\sim 8.4-9.1$ & $\sim 14.5-15.08$ \\
Crust-Mantle & $\sim 13.5-19$ & \\
\hline
\end{tabular}

From the analytic signal map of EMAG2, the magnetic sources (figure $7 \mathrm{~b}$ ) to the north of L1 trend in $\mathrm{E}-\mathrm{W}$ direction, while towards south they mainly trend in NW-SE direction (also within the Laxmi Basin) until they are terminated by NE-SW sources cutting across both the Laxmi Ridge and Basin. The identified magnetic lineations (Müller et al. 2008) of the Arabian Sea (A28) and Gop Rift (A29) (Yatheesh et al. 2009) are superposed on analytic signal map (figure 7b).

\section{Results and discussion}

High resolution satellite-derived FAG along with ship-borne gravity, magnetic and EMAG2 data over the Laxmi Ridge and the adjoining Arabian, Laxmi, and Gop Basins were analysed to throw light on the crustal architecture of these tectonic elements. 2D models along selected profiles and 3D models using MWT, both working under different assumptions, were derived to understand the crustal configuration of the Laxmi Ridge and the adjoining regions. Frequency domain filtering and gradient analysis were carried out to isolate the gravity and magnetic sources at different depth levels. The magnetizations and crustal structure deduced from the 2D crustal modelling along profile 1 , is in agreement with sea-floor spreading type anomalies on either side (both in Arabian and Gop Rift Basins) of the Laxmi Ridge (figure 4a). Whereas, along profiles 2 and 3, seafloor spreading type anomalies were confined only to the Arabian Basin. The crustal structure deduced from 2D and 3D models, constrained by refraction velocity data, shows that thick lower crust overlies Moho in the EW segment, while the
Moho is overlain by almost $10-\mathrm{km}$ thick underplated material in the NW-SE segment. The presence of high velocity layer (figure $4 \mathrm{~b}-\mathrm{e}$ ) between the lower crust and mantle (Laxmi Ridge) in the NW-SE part of the ridge matched reasonably well with Horizon 4 (horizon depths, figure 5) obtained from the MWT analysis. When compared, the depth to the top of the underplated layer and the depth to Moho obtained from the forward modelled 2D crustal structure (figure 4) matched fairly well with the depths obtained from the MWT method (figure 5); thus giving credence to the calculated depths. Similarly, presence of underplated material was not seen in 2D model as well as 3D model in $\mathrm{E}-\mathrm{W}$ section of LR. The absence of underplated material in the EW part of LR was also seen along a profile (SG2) running through the EW and NWSW part. But studies by Minshull et al. (2008) have shown presence of underplated material below the EW part of the Laxmi Ridge whereas potential field modelling did not reveal their presence. This may possibly be due to two reasons: (1) the underplating may be too thin to generate a signature in gravity and magnetic data, (2) due to compositional changes a detectable density contrast may not be existing between the underplated and adjacent layers. We would like to mention here that a velocity contrast of only $0.2 \mathrm{~km} / \mathrm{sec}$ is observed between underplated and adjacent layer in seismic velocity model of Minshull et al. (2008). Several high frequency gravity and magnetic signatures, probably representing intrusives, are observed in the NWSE segment but absent in the EW segment of LR. Even in the deeper part, EW segment of the Laxmi Ridge is characteristically different from the NWSE segment. From the filtering and analytic signal, we found that the gravity and magnetic sources are mainly concentrated on the NW-SE segment of the Laxmi Ridge at shallow levels. Isopach map derived from seismic velocities (Schreider et al. 2002) shows a thin sediment cover of $1-2 \mathrm{~km}$ over the NW-SE segment, while it increases to $3-4 \mathrm{~km}$ on the EW segment of the ridge. Summarising the results, we find (a) presence of underplated material in the NW-SE part of LR while it is absent in EW part and (b) intrusives/sources concentrated in the NW-SE part but absent in the EW. An EW trending magnetic high (L1 in figure 3) seen in the EMAG2 coincides with the region where the two parts of the Laxmi Ridge change its character suggesting that L1 is marking a boundary between the E-W and NW-SE segments of the Ridge. The NE-SW trending Girnar fracture zone (figure 1) (Malod et al. 1997), a possible strike-slip zone north of Laxmi Basin, if extended further southwest passes through this region where the character of Laxmi Ridge changes. The thickened crust deduced within the LR, the densities 


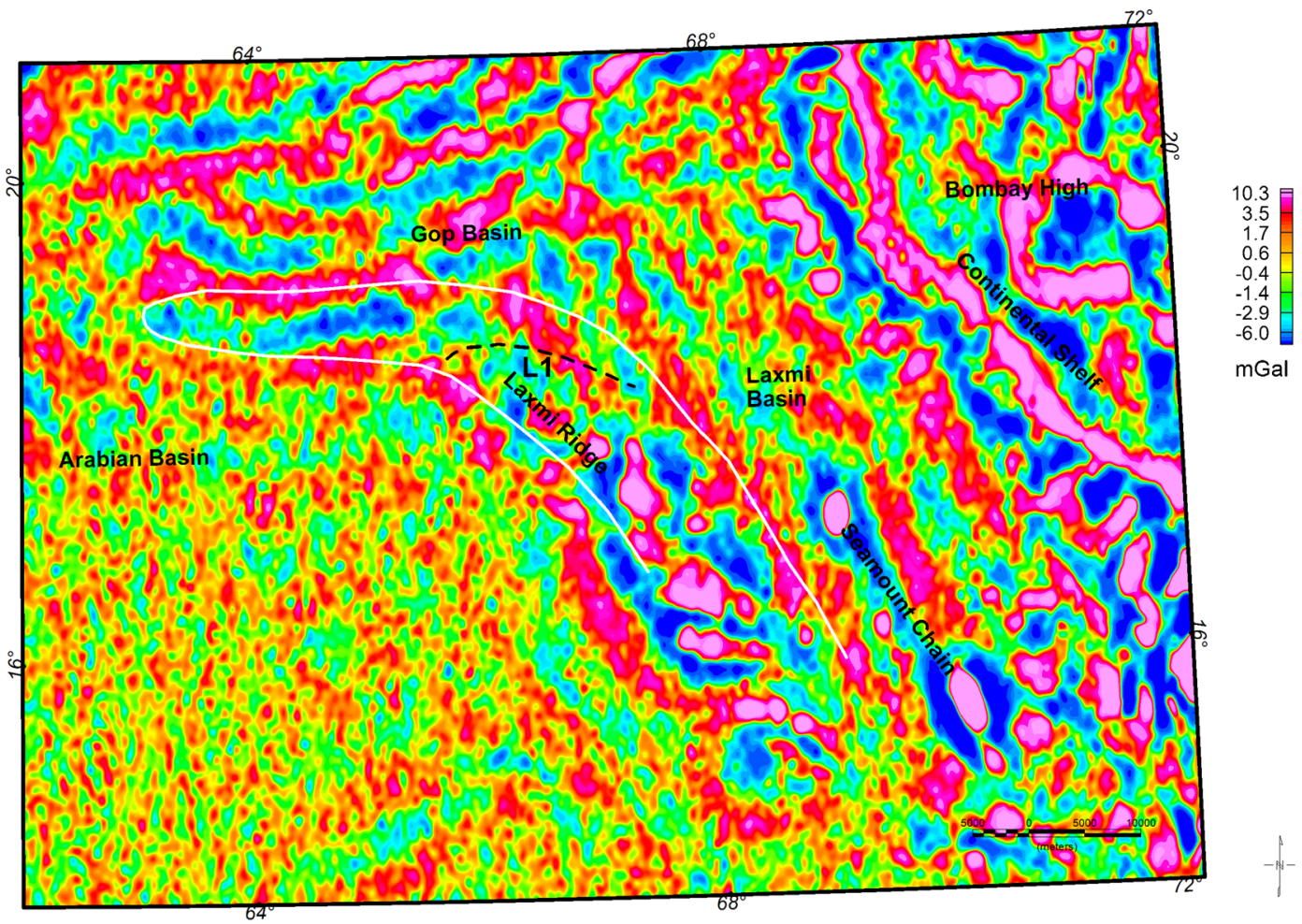

(a)

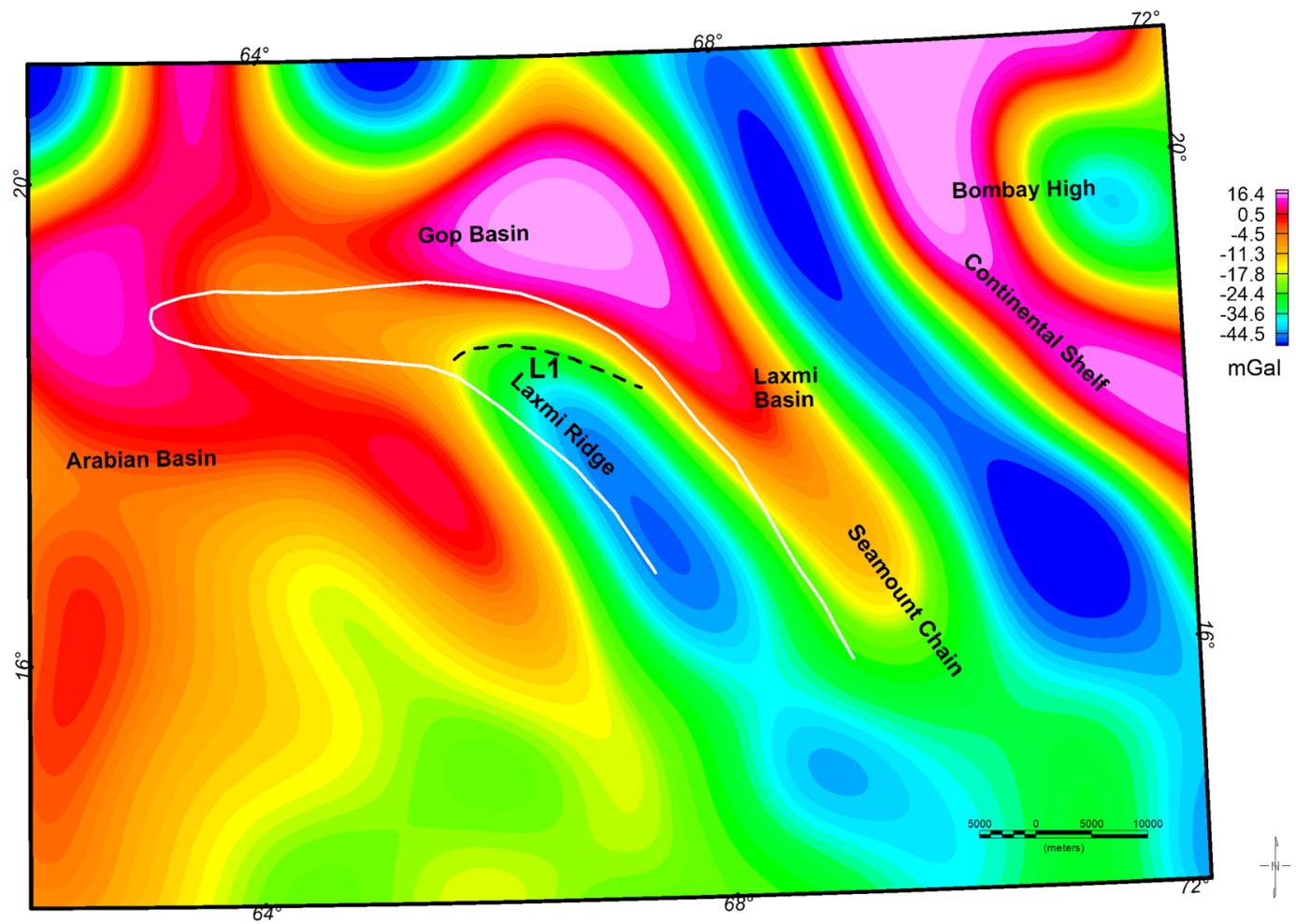

(b)

Figure 6. Filtered FAG maps: (a) High pass filtered maps with cut off wavelengths $100 \mathrm{~km}$, (b) low pass filtered map with cut-off wavelength of $200 \mathrm{~km}$. Mapped in thick white is the outline of the Laxmi Ridge demarcated from Minshull et al. (2008) and marked in black dashed line is L1 as discussed in the text.

obtained from the seismic velocities along the LR, and the absence of spreading anomalies over the ridge suggest it to be of continental type (figure 4) as stated by Naini and Talwani (1982) and later studies. Thus one of the hitherto unknown results of the present study is that the Laxmi Ridge is 


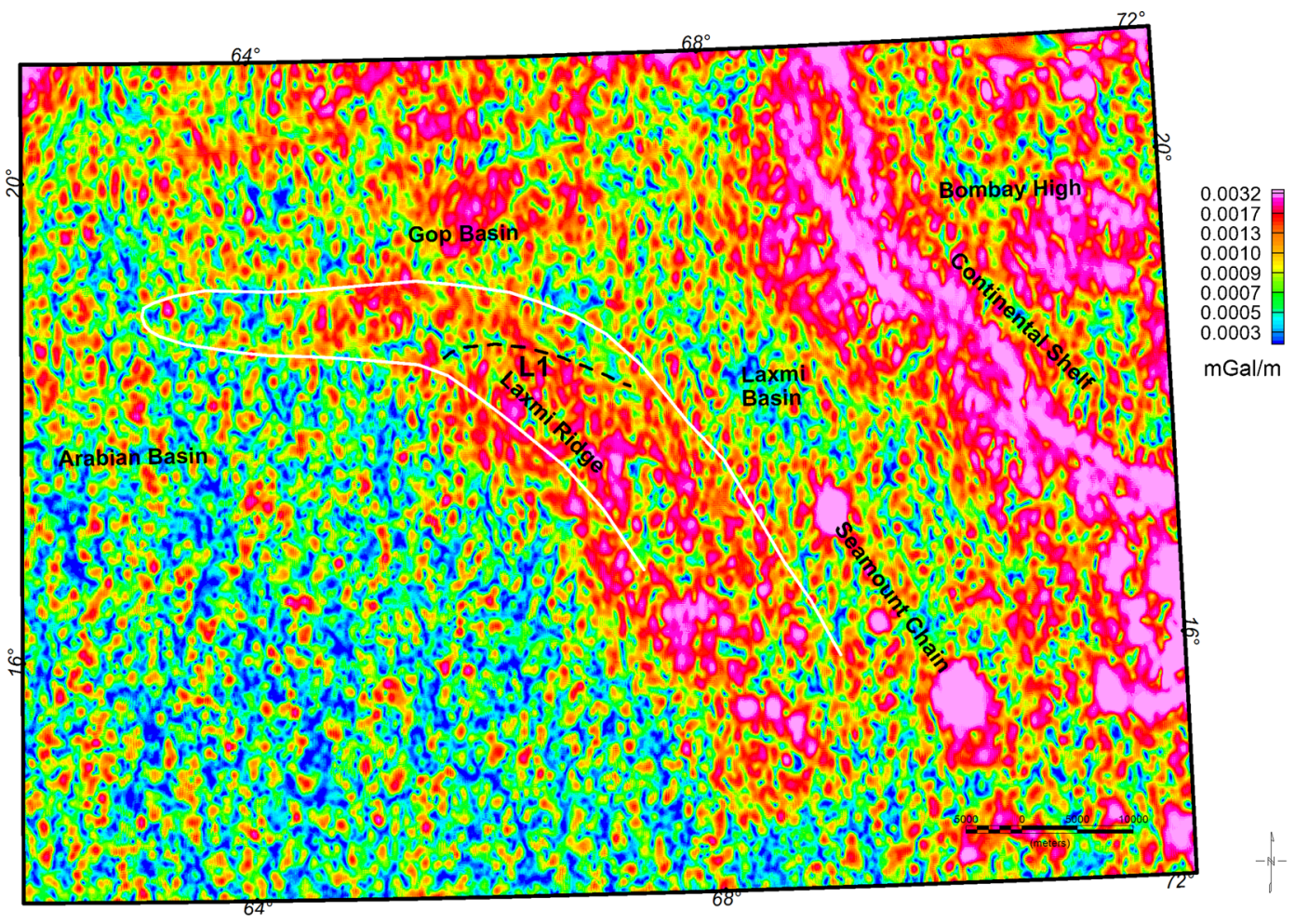

(a)

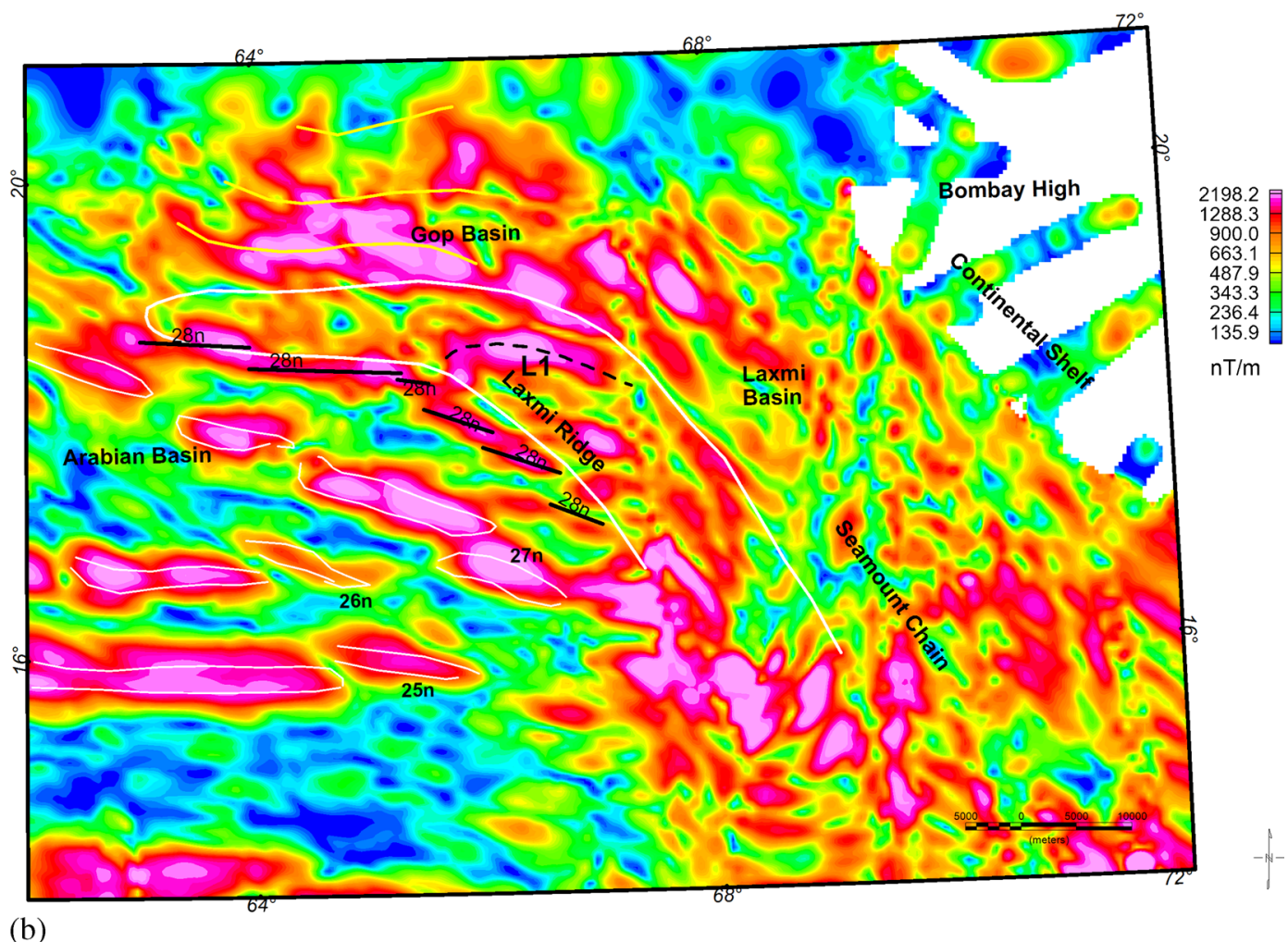

Figure 7. Analytic signal map of the (a) FAG and (b) EMAG2 data. Superposed are the demarcation of Laxmi Ridge (in white) from Minshull et al. (2008), the magnetic lineations labelled after Chaubey et al. (2002), Yatheesh et al. (2009) and the lineament L1 (black dashed line) identified from figure 3.

divided into an EW and NW-SE segment which possibly has different evolutionary history resulting in difference in the nature of the crust.
Second result inferred from the present study is that the region to the northwesternmost part of Laxmi Basin is composed of volcanic/basaltic flows 
rather than sea-floor anomalies or intrusives. The presence of volcanic/basaltic flows in this region can arise due to the following possibilities:

(a) these are emplaced on an already existing crust as India moved over a hotspot such as Reunion

(b) volcanism associated with the rifting of Laxmi Ridge from its counterpart

(c) localized volcanism emplaced due to impact of meteriorites such as the one which gave rise to Somnath volcanism (Chatterjee et al. 2013).

The remanent magnetic inclination $\left(I_{r}\right)$ obtained for these volcanic flows (profiles 2 and 3) were approximately $-50^{\circ}$. Assuming that the geomagnetic field is that of a dipole at the centre of the Earth, the palaeomagnetic latitude $(\lambda)$ of a position/location is calculated from the remanent inclination $\left(I_{r}\right)$ of its magnetic field by $\lambda=\tan ^{-1}((\tan$ $\left.\left.I_{r}\right) / 2\right)$ or $\left[\tan I_{r}=2 \tan \lambda\right]$ suggesting the palaeolatitude at the time of volcanic flow would be $\sim 30^{\circ} \mathrm{S}$. This location more or less matches with the palaeo-plate reconstruction model of Müller et al. (1993). The well identified sea-floor spreading anomalies in the Gop Basin (Malod et al. 1997) was explained either as A31r-A25r ( 69.3- 56.4 Ma) or as A29r-A25r ( 64.8-56.4 Ma) by Yatheesh et al. (2009). Also, integrated geophysical studies by Krishna et al. (2006) have shown that the Laxmi Basin is a failed rift formed prior to Deccan volcanism and that the magnetic anomalies arise due to the intrusives emplaced into this stretched crust by the Reunion hotspot rather than spreading anomalies as deciphered by Bhattacharya et al. (1994). Both the above-mentioned studies suggest that the region to the north of Laxmi Ridge is formed prior to the main Deccan activity. The present location of Reunion plume is around $21^{\circ} \mathrm{S}$. Considering the studies by Craig et al. (2003) who suggested that the Reunion hotspot drifted northwards by $5^{\circ}$ to reach its present position during the period 55-35 Ma, the inclination of $-50^{\circ}$ obtained for the volcanic flows can be related to Deccan volcanism. Further, paleomagnetic studies conducted on the dykes of Kutch Rift Basin indicated a mean remanent inclination of $-45^{\circ}$ and have been assigned Deccan affinity (Venkateshwarlu et al. 2014). The present location (latitude) of these dykes are $\sim 23.5^{\circ} \mathrm{N}$ and the region between Laxmi and Gop Basins $\sim 19.5^{\circ} \mathrm{N}$. This suggests that not much movement has taken place between the Kutch Rift Basin and the Laxmi Ridge after their formation; also the volcanic flows in the region north of LR and dykes in the Kutch Basin may be contemporaneous. The magmatic activity in the Kutch Rift Basin leading to the formation of these dykes is coeval with the Deccan lava eruption (Paul et al. 2008). From the isotopic and chemical compositions of the basalts from the Kutch and Mumbai Offshore Basins, Rathore et al. (2013), suggest that the basalts in these basins falls to Within Plate Basalts (WPB) category similar to on-land Deccan trap. Hence, the volcanic flows deduced from the present study may be related to the passage of India over Reunion plume. Further analysis and interpretation is required to confirm the present findings, as this inference is made from interpretation of two widely-spaced profiles.

The main findings from the present study include: (a) the nature of the EW segment of the Laxmi Ridge is different from the NW-SE segment; no underplating is observed below EW segment while it was seen below the NW-SE segment; (b) the southwest extension of the Girnar fracture zone appears to be the line of divide between these two segments; (c) the region to the north of Laxmi Ridge, between Laxmi and Gop Basins is composed of volcanic/basaltic flows having Deccan affinity, emplaced in the already existing crust. The present study also supports the previous findings of Malod et al. (1997) and Yatheesh et al. (2009), that the Gop Basin is composed of spreading anomalies. The magnetic anomalies in the Gop Basin indicate that the basin opened between 73 and $68 \mathrm{Ma}$ (Malod et al. 1997; Collier et al. 2008) before the Deccan plume activity with the Palitana Ridge as the extinct spreading center (Yatheesh et al. 2009). Armitage et al. (2010) suggested that the opening of the Gop Basin may have preceded the main Deccan eruption by $6 \mathrm{My}$. Integrating the present study results with the results of Krishna et al. (2006) and Armitage et al. (2010), it can be inferred that volcanic material having Deccan affinity is emplaced on a stretched continental crust which is limited towards the west by the Girnar fracture zone. The NW-SE segment of the Laxmi Ridge is associated with underplating while it is not found below the EW part. If underplating is a necessary pre-requisite for any rifting mechanism, then we infer that Seychelles was attached only to the NW-SE segment of the Laxmi Ridge which was later separated forming the present Arabian Basin. We speculate that the initial rifting of India from Madagascar-Seychelles-Laxmi RidgeLaccadive Ridge took place prior to the passage of Indian plate over the Reunion hotspot, possibly related to the Marion hotspot activity during $85 \mathrm{Ma}$ (Yatheesh et al. 2006). But due to some reasons, the rifting got aborted after a given time interval, forming a failed rift, thereby forming a platform for the accumulation of sediments in these failed rift grabens. This is supported by the interpretation of the reprocessed seismic data in the Kerala-Konkan and Mumbai Off-shore basins that suggests the presence of Mesozoic sediments below the trap flows (Roberts et al. 2010; Gorain 2012; Kalra et al. 
2014). Later, the passage of Indian plate over Reunion hotspot has left its imprints in the form of intrusvies into the stretched continental crust (Krishna et al. 2006) as well as the existing crust of Laccadive Ridge, etc. (Nair et al. 2013). This also may have triggered the rifting between Laxmi Ridge (NW-SE segment) and the Seychelles giving rise to the well-defined anomaly A28 ( $\sim 63 \mathrm{Ma})$ belonging to the Arabian basin.

\section{Summary}

Using wavelength filtering analysis and source distributions along with 2D and 3D crustal modelling of the satellite-derived FAG and ship-borne gravity/magnetic data, we have revisited the crustal architecture of the Laxmi Ridge and adjoining regions in the north-eastern Arabian Sea.

- The crustal structure deduced from 2D modelling suggests that the Laxmi Ridge is divided into two distinct segments such that a thick lower crust overlies Moho in the EW segment while the Moho is overlain by a thick underplated material in the NW-SE segment of the Laxmi Ridge.

- 3D crustal structure derived using Energy Spectral Analysis (ESA), a method very different from 2D modelling, depicts depth horizons representing interface between different layers. The $3 \mathrm{D}$ crustal structure deduced using ESA also reconfirms similar geometry for the Laxmi Ridge as obtained from the 2D forward model.

- Results from the filtering and source distribution suggest that the intrusives/sources are concentrated in the NW-SE part of the Laxmi Ridge, while they are absent or very minimal in the EW segment.

- From the present study, we infer that the division of the Laxmi Ridge into an EW and NWSE segments with varied evolutionary history is possibly controlled by the Girnar fracture zone. The southwest extension of the Girnar fracture zone appears to mark the boundary between the E-W and NW-SE segments of the Ridge, which depict structurally and characteristically different nature.

- From the calculated inclination parameters derived from the best fit $2 \mathrm{D}$ model we infer that the region to the north of Laxmi Ridge, the northwestern part of Laxmi Basin, is composed of volcanic/basaltic flows having Deccan affinity that might have been emplaced in an already existing crust. Integrating the results from the present study with previous studies suggests that the rifting in the Gop Basin preceded the emplacement of the volcanics in the region between Laxmi and Gop Basins. The emplacement of volcanic/basaltic flows may be associated with the passage of India over the Reunion hotspot.

\section{Acknowledgements}

This work was carried out under Meteorology and Oceanographic Program - Phase II of Dept. of Space, Govt. of India. Ms. Nisha Nair, Senior Research Fellow under this project wishes to thank Dept. of Space for their financial assistance.

\section{References}

Agarwal P K, Pandey O P and Negi J G 1992 Madagascar: A continental fragment of the paleo-super Dharwar craton of India; Geology 20 543-546.

Anand S P, Rajaram M, Majumdar T J and Bhattacharyya R 2009 Structure and tectonics of $85^{\circ} \mathrm{E}$ Ridge from analysis of geopotential data; Tectonophys. 478 100110.

Armitage J J, Collier J S and Minshull T A 2010 The importance of rift history for volcanic margin formation; Nature $465913-917$.

Arora K, Tiwari V M, Singh B, Mishra D C and Grevemeyer I 2012 Three dimensional lithospheric structure of the western continental margin of India constrained from gravity modelling: Implication for tectonic evolution; Geophys. J. Int. 190 131-150, doi: 10.1111/j.1365-246X.2012.05506.x.

Bansal A R, Fairhead J D, Green C M and Fletcher M U 2005 Revised gravity for offshore India and the isostatic compensation of submarine features; Tectonophys. 404 $1-22$.

Bhattacharya G C and Chaubey A K 2001 Western Indian Ocean - a glimpse of the tectonic scenario; In: The Indian Ocean - A perspective (eds) Sen Gupta R and Desa E, Oxford-IBH, New Delhi, pp. 691-729.

Bhattacharya G C, Chaubey A K, Murthy G P S, Srinivas K, Sarma K V L N S, Subrahmanyam V and Krishna K S 1994 Evidence for seafloor spreading in the Laxmi Basin, northeastern Arabian Sea; Earth Planet. Sci. Lett. 125 $211-220$.

Chatterjee S, Goswami A and Scotese C R 2013 The longest voyage: Tectonic, magmatic, and paleoclimatic evolution of the Indian plate during its northward flight from Gondwana to Asia; Gondwana Res. 23(1) $238-267$.

Chaubey A K, Dyment J, Bhattacharya G C, Royer J Y, Srinivas K and Yatheesh V 2002 Paleogene magnetic isochrons and palaeo-propagators in the Arabian and eastern Somali basins, NW Indian Ocean; In: The tectonic and climatic evolution of the Arabian Sea region (eds) Clift P D, Croon D, Gaedicke C and Craig J, Geol. Soc. London, Spec. Publ. 195 71-85.

Chaubey A K, Bhattacharya G C, Murthy G P S, Srinivas K, Ramprasad T and Gopala Rao D 1998 Early Tertiary seafloor spreading magnetic anomalies and paleopropogators in the northern Arabian Sea; Earth Planet. Sci. Lett. 154 41-52.

Collier J S, Sansom V, Ishisuka O, Taylor R N, Minshull T A and Whitmarsh R B 2008 Age of Seychelles-India break-up; Earth Planet. Sci. Lett. 272 264-277. 
Craig O'Neill, Müller D and Steinberger B 2003 Geodynamic implications of moving Indian Ocean hotspots; Earth Planet. Sci. Lett. 215 151-168.

Dyment J, Cande S C and Arkani-Hamed J 1994 Skewness of marine magnetic anomalies created between 85 and $40 \mathrm{Ma}$ in the Indian Ocean; J. Geophys. Res. 99(B12) 121124.

Gopala Rao D, Ramana M V, Bhattacharya G C, Subba Raju L V, Kamesh Raju K A and Ramprasad T 1992 Marine geophysical studies along a transect across the continental margin of Bombay coast, west of India, In: Oceanography of the Indian Ocean (ed.) B N Desai, IBH Publications, New Delhi, pp. 493-501.

Gorain S 2012 Mesozoic prospectivity of Kerala Konkan Offshore Basin; $9^{\text {th }}$ Biennial International Conference \& Exposition on Petroleum Geophysics, Hyderabad.

Kalra R, Srinivasa Rao G, Roberto Fainstein, Radhakrishna M, Rabi Bastia and Chandrashekar S 2014 Crustal architecture and tectono-magmatic history of the western offshore of India: Implications on deepwater subbasalt hydrocarbon exploration; J. Petrol. Sci. Eng., doi: 10.1016/j.petrol.2014.07.002.

Kent G, Harding A and Orcutt J 1993 Distribution of magma beneath the east Pacific Rise between the Clipperton Transform and the $9^{\circ} 17^{\prime} \mathrm{N}$ Deval from forward modelling of common depth point data; J. Geophys. Res. 98 13,945-13,969.

Kolla V and Coumes F 1990 Extension of structural and tectonic trends from the Indian subcontinent into the eastern Arabian Sea; Mar. Petrol. Geol. 7 188-196.

Krishna K S, Rao D G and Sar D 2006 Nature of the crust in the Laxmi Basin $\left(14^{\circ}-20^{\circ}\right)$, western continental margin of India; Tectonics 25(TC1006), doi: $10.1029 / 2004$ TC001747.

Long A 2010 The use of different type of velocity data and their application to gravity modelling; Technical paper, Geosoft Inc.

Malod J A, Droz L, Kemal B M and Patriat P 1997 Early spreading and continental to oceanic basement transition beneath the Indus deep-sea fan: Northeastern Arabian Sea; Mar. Geol. 141 221-235.

Markham S L, Kivior I, Vaughan F V, Yates S and Barnden S 2008 Testing survey resolution using spectral analysis; EAGE workshop on 'The Future of Non-Seismic Methods' 12-15 October 2008, Manama, Bahrain.

Maus S, Barckhausen U, Berkenbosch H, Bournas N, Brozena J, Childers V, Dostaler F, Fairhead J D, Finn C, von Frese R R B, Gaina C, Golynsky S, Kucks R, Luhr H, Milligan P, Mogren S, Muller D, Olesen O, Pilkington M, Saltus R, Schreckenberger B, Thebault B and Caratori Tontini F 2009 EMAG2: A 2-arc minute resolution earth magnetic anomaly grid compiled from satellite, airborne and marine magnetic measurements; Geochem. Geophys. Geosyst. 10 Q08005, doi: 10.1029/2009GC002471.

Miles P R and Roest W R 1993 Earliest sea-floor spreading magnetic anomalies in the north Arabian Sea and the ocean-continent transition; Geophys. J. Int. 115 10251031.

Miles P R, Munschy M and Segoufin J 1998 Structure and early evolution of the Arabian Sea and East Somali Basin; Geophys. J. Int. 134 876-888.

Minshull T A, Lane C I, Collier J S and Whitmarsh R B 2008 The relationship between rifting and magmatism in the northeastern Arabian Sea; Nat. Geosci. $1463-467$.

Mukhopadhyay R, Karisiddaiah S M and Ghosh A K 2012 Geodynamics of the Amirante Ridge and Trench Complex, western Indian Ocean; Int. Geol. Rev. 54(1) 81-92.

Müller R D, Royer J Y and Lawver L A 1993 Revised plate motions relative to the hotspots from combined Atlantic and Indian Ocean hotspot tracks; Geology 21 275-278, doi: 10.1130/0091-7613.

Müller R D, Sdrolias M, Gaina C and Roest W R 2008 Age, spreading rates and spreading symmetry of the world's ocean crust; Geochem. Geophys. Geosyst. 9 Q04006, doi: 10.1029/2007GC001743.

Nabighian M N 1972 The analytical signal of twodimensional magnetic bodies with polygonal cross section: Its properties and use for automated anomaly interpretation; Geophysics 37 507-517.

Nabighian M N 1974 Additional comment on the analytical signal of two dimensional magnetic bodies with polygonal cross section; Geophysics 39 85-92.

Nafe J E and Drake C L 1963 Physical properties of marine sediments; In: The Sea (ed.) Hill M N, Wiley Intersciences, New York, 3 794-815.

Naini B R 1980 A geological and geophysical study of the continental margin of western India, and the adjoining Arabian Sea including the Indus Cone, Ph.D. thesis, Columbia Univ., New York, 173p.

Naini B R and Talwani M 1977 EOS-Trans; Am. Geophys. Union $\mathbf{5 8} 405$.

Naini B R and Talwani M 1982 Structural framework and the evolutionary history of the continental margin of western India; In: Studies in Continental Margin Geology (eds) Watkins J S and Drake C L, Am. Assoc. Petrol. Geol. Memoir 34 167-191.

Nair N, Anand S P and Rajaram M 2013 Tectonic framework of Laccadive Ridge in Western Continental Margin of India; Mar. Geol. 346 79-90.

National Geophysical Data Centre Sediment thickness data 2003 http://www.ngdc.noaa.gov/mgg/sedthick/sedthick. html.

Pandey O P, Agarwal P K and Negi J G 1995 Lithosphreric structure beneath Laxmi Ridge and late Cretaceous geodynamic events; Geo-Mar. Lett. 15 85-91.

Paul D K, Ray A, Das B, Patil S K and Biswas S K 2008 Petrology, geochemistry and paleomagnetism of the earliest magmatic rocks of Deccan Volcanic Province, Kutch, northwest India; Sci. Direct 102 237-259, doi: 10.1016/j.lithos.2007.08.005.

Radha Krishna M, Verma R K and Purushotham A K 2002 Lithospheric structure below the eastern Arabian Sea and adjoining west coast of India based on integrated analysis of gravity and seismic data; Mar. Geophys. Res. 23 25-42.

Rajaram M, Anand S P, Hemant K and Purucker M E 2009 Curie isotherm map of Indian subcontinent from satellite and aeromagnetic data; Earth Planet. Sci. Lett. 281 $147-158$.

Rajaram M, Anand S P and Majumdar T J 2011 Structure and tectonics of the Indian offshore region from satellitederived geopotential data; In: Proceedings of the Second Swarm International Science Meeting held at GFZ, Potsdam, Germany, Vol. 24.

Rathore S S, Kumar R, Uniyal G C and Upadhyay H 2013 Chemical composition and $\mathrm{Sr}-\mathrm{Nd}$ isotopic studies of basement rocks from Kerala-Konkan Offshore basin of India: Implications on future exploration; 10th Biennal International Conference \& Exposition, Kochi.

Roberts G, Harmer C, Rutherford K and Colin O'Brien 2010 Deep water west coast India - The opening of a new play beneath the Deccan Basalts; Spectrum Geo Technical Paper Ref. 20549

Samal J K, Dwivedy R N and Mayor S 2012 Magmatic seismo-facies and crustal architecture along selected profiles in Arabian Sea, west coast of India, The 2nd South Asian Geoscience Conference and Exhibition, GEO India 2011, New Delhi, India. 
Sandwell D T and Smith W H F 1997 Marine gravity anomaly from Geosat and ERS 1 satellite altimetry; J. Geophys. Res. 102 10,039-10,054.

Sandwell D T and Smith W H F 2009 Global marine gravity from retracked Geosat and ERS-1 altimetry: Ridge segmentation versus spreading rate; J. Geophys. Res. 114 B01411, doi: 10.1029/2.

Sandwell D T, Garcia E, Soofi K, Wessel P and Smith W H F 2013 Towards 1 mGal Global Marine Gravity from CryoSat-2, Envisat, and Jason-1, The Leading Edge.

Schreider A A, Mazo E L, Bulychev A A, Gainanov A G and Schreider Al A 2002 Features of sedimentation in the north of the Arabian Sea; Oceanology 42 585593.

Singh A P 1999 The deep crustal accretion beneath the Laxmi Ridge in the northeastern Arabian Sea: The plume model again; J. Geodyn. 27 609-622.

Storey M, Mahoney J J, Saunders A D, Duncan R A, Kelley S P and Coffin M F 1995 Timing of hotspot-related volcanism and the breakup of Madagascar and India; Science $267852-855$.

Talwani M, Worzel J I and Landisman M 1959 Rapid gravity computations for two dimensional bodies with application to the Mendocino submarine fracture zone; J. Geophys. Res. 64 49-59.
Talwani M and Heirtzler J R 1964 Computation of magnetic anomalies caused by two dimensional bodies of arbitrary shape; In: Computers in the mineral industries, Part 1 (ed.) Parks G A, Stanford University Publication, Geol. Sci. 9 464-480.

Todal A and Edholm O 1998 Continental margin off western India and Deccan Large Igneous Province; Mar. Geophys. Res. 20 273-291.

Venkateshwarlu M, Pandey B, Pappanna G, Pathak D B and Krishna J 2014 New Palaeomagnetic evidences about Deccan Trap Volcanic activity from the magmatic bodies of Kachchh Basin, northwest India; J. Ind. Geophys. Union 18(1) 99-107.

Won I J and Bevis M G 1987 Computing the gravitational and magnetic anomalies due to a polygon: Algorithms and Fortran subroutines; Geophys. 52 232-238.

Yatheesh V, Bhattacharya G C and Mahender K 2006 The terrace like feature in the mid continental slope region off Trivandrum and a plausible model for India-Madagascar juxtaposition in immediate pre-drift scenario; Gondwana Res. 10(1-2) 179-185.

Yatheesh V, Bhattacharya G C and Dyment J 2009 Early oceanic opening off western India pakistan margin: The Gop basin revisited; Earth Planet. Sci. Lett. 284 399408, doi: 10.1016/j.epsl.2009.04.044. 